\title{
How Should Public Procurement Law Deal With FinTech?
}

\author{
Bryane Michael, University of Hong Kong
}

\begin{abstract}
FinTech -- along with the blockchain, other distributed ledger, smart contract, and tokenization usually assumed to accompany it -- could change the way governments procure goods and services. Procurement authorities and procurement law can play a vital role in the development of FinTech. They can help build the FinTech platforms and ecosystems that help them engage in public procurement. They should not try to procure such FinTech outright. At the national level, regulators should not just leave FinTech rulemaking up to financial regulators. Contracting authorities should not just develop or use their own selected FinTech applications willy-nilly. They should contribute to overall changes in procurement law - which extend far beyond simple supervisory or regulatory technologies (RegTech/SupTech). Governments should get serious about the Agreement on Government Procurement and similar treaties - by creating a new authority to help develop the law needed to put FinTech-enabled procurement platforms in place. China's own world-leading FinTech and cross-border public procurements do not always contribute to a global level playing field. Any FinTech applications facilitating public procurement should thus encourage compliance with the procurement law legal principles the international community has developed over decades.
\end{abstract}

JEL Codes: H57, E63, G21

Keywords: public procurement, financial technology, FinTech, Conflict of interest disclaimer: I have received no extra personal benefits from this research, either pecuniary or otherwise.

Data availability statement: No data to disclose

Acknowledgements: I/we gratefully acknowledge the Research Impact Fund Balancing the Opportunities and Risks of Financial Technology: FinTech Regulation and Policy (Grant number R7054-18). We also thank King's College London for their help and support while writing this piece. 


\section{Contents}

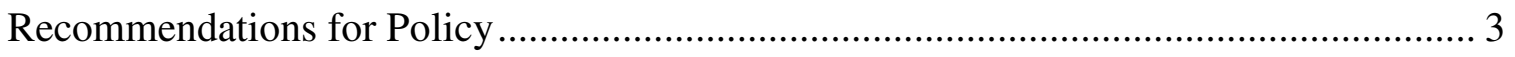

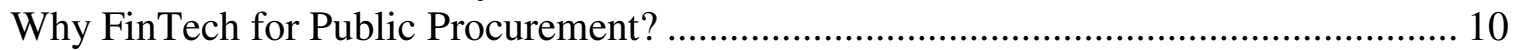

The Four Aspects of Our Working Definition of FinTech? .................................... 10

FinTech's Application to Public Procurement............................................................ 12

The Promises and Pitfalls of FinTech in Public Procurement .................................... 18

Why Should We Care About Procurement Principles? ............................................ 22

The Principles Involved in Procuring a FinTech System .......................................... 26

The Costs and Benefits of Procuring a FinTech Ecosystem/Standards ...................... 26

Principles in Procuring a National FinTech-Based Procurement Financing System ... 28

Is FinTech Procurement a Service of General Public Interest... Or State Aid?........... 30

Putting FinTech into Procurement Law: Preventing a Free-For-All ............................. 33

Can Contracting Authorities Let a Thousand FinTech Flowers Bloom? ................... 33

From SupTech/RegTech toward a Centralized Procurement Law ............................. 36

Contours of FinTech-Enabled Procurement Law ...................................................... 39

Preventing a Free-For-All in International Procurement Standards .............................. 42

The Promise of FinTech in Revitalizing Government-to-Government Procurement... 42

Could FinTech Breath New Life into International Procurement Law?..................... 44

Chinese FinTech and Belt-and-Road Based Procurement as a Threat to Established

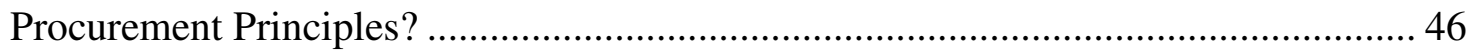

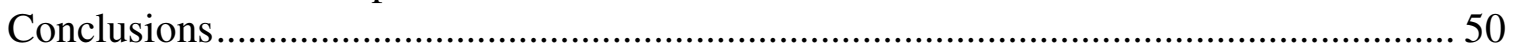




\section{Recommendations for Policy}

\section{Domestic/Union-Wide}

1. Multi-stakeholder commissions. FinTech regulation involves more than just financial (and especially banking) regulators. Other bodies, like centralized procurement agencies arranging for FinTech-enabled procurements, should have a voice at a multi-stakeholder commission, board or working group. Such a commission can also consider the policies aimed at avoiding anti-competitive behaviour -- like the mandatory sharing of algorithmic learning, subsidization of competitors, the temporary shutdowns of any FinTech platform developed or managed by the government and so forth.

2. Independent, non-government procurement authorities? Private sector, technologists and financial experts will need some control over some aspects of seniorlevel procurement policy/practice. If public-private commissions can not oversee central procurement bodies, than 'twin peaks' style regulations may allow for private sector participation in a regulatory body, and civil servants in the market conduct bodies. Such bodies can also help decide on public versus private information on distributed ledgers like blockchains. They can also lead efforts in adopting, at the regulatory level, the UNCITRAL's and other organizations' work in on encouraging FinTech applications in areas such as receivables assignment, secured transactions, IP security rights and registries, and secured transactions.

3. FinTech-regulation. Vest the central procurement agency or related body with the regulatory ability to mandate changes to the rules governing the ancillary parts of procurement where FinTech plays a role. Allow for explicit FinTech-related rulemaking (and do fast, given the delays in e-procurement). Even if national law does not allow for accepting tokens or ledger data as part of a contract, procurement rules (as repeated in procurement invitations and contracts) may allow agencies to use them.

4. FinTech-based finance satisfying financial standing. Amend procurement legislation to allow bidders' to use FinTech applications as a means of demonstrating economic and financial standing when submitting bids. Clearly, capacity for crowdfinance or just-in-time funding should count as financial reserves to some extent.

5. Recognize tokens and signed ledgers as legal. Legislators need to make explicit provision for digital information in procurement law (and preferably across the supply chain). Domestic legislation needs to recognize digitally secure information or tokens (in cryptographic/digital form) with the same legality as paper documents showing the movement in goods and money or the securitization of assets/liabilities.

6. FinTech-ecosystems as in-house or outhouse -- not both. Procurement authorities seek to fund FinTech using pre-commercial procedures and otherwise 'buy' FinTech from existing market players. Yet, they also spend large amounts of money in-house, collaborating across public sector authorities to build FinTech 'pilot' projects. Running 
both systems (even if not concurrently) wastes money, competes against yourself, and hurts overall innovation.

7. Procurement sandboxes. Do not let individual contracting authorities to run their own self-designed sandbox FinTech-enabled procurements. Agree as a procurement system which procurements will be tried, why -- and what is to be learned. Ensure bidders have full and fair disclosure of the experiment.

8. Public-private partnership from blockchain to token. If governments are keen to conduct FinTech experiments, they may use the four technologies we discussed as 'FinTech-enabled' to run a public-private partnership (PPP) under their own country's procedure for such PPPs. Such a procurement doesn't need to involve FinTech as the principle subject of the contract (like funding a motorway).

9. Putting 'subsidy tokens' online. If FinTech support constitutes a 'service of general economic interest' then terms should be same as others -- namely with a calculation of the costs and benefits, the potential subsidization, and the transparent tracking of such 'advantage.' Governments can use blockchains to monitor the way such quanftified advantages 'filter' across the economy.

10. Insurer delight and caution. Make provision in procurement law (and insurance law if necessary) to allow for the mutualization of risks involved in procurement beyond contracting parties to beneficiaries. Unlike traditional insurance markets, many risks involve us all and will be cheaper to crowd-insure than rely on government as insurer-oflast-resort.

11. Traceable 'taxes'. Authorize the payment of pilot project 'taxes' in cryptocurrency formats like any local currency, with local budget law providing potential carve-outs for FinTech pilots.

12. National budget law review. Have the experts advising in the multi-stakeholder forum review the Budget Law with line-by-line proposals for introducing FinTech in future procurement budgeting. Such work can consist of procedures accounting for securitized assets, methods for accounting for Fin-Tech carve-out pilots in the general accounts, and reports assembled from data coming off of FinTech applications.

13. Digital IDs for contracting authorities. Ensure that every contracting authority has a unique identification, wallet and other information to ensure consistent identification across platforms and to encourage future use in cryptographically signed applications.

14. Several simple steps. Some countries may find a national referendum on FinTech in procurement, the adoption of an "innovation principle" into law, requirements for breakpoints in decentralized autonomous organizations (DAOs), as well as PR work around national e-portals of use. 
1. No more FinTech in-house or external procurement funding for member state bodies. Bodies like the WEF, IADB, WB and others have increasingly participated in procuring FinTech services. Such procurements distort markets. Yet, building up FinTech expertise in their own organizations gives these people and project undo subsidies and advantages over those having to do this work outside the international organizations. A lot of such FinTech work is white-wash anyway.

2. An International Public Procurement Authority (IPPA). Far less important policy areas get their own international secretariats. An international organization -- like the proposed IPPA -- should encourage FinTech development which is neutral to the market traditions of their member states and help establish a level playing field for all crossborder procurement.

3. Putting FinTech into International Procurement Law. Diplomats and treaty writers do not need to wait for the IPPA's recommendations. Bodies like the UNCITRAL and the GPA working groups should write in FinTech now -- even if the final contours remain to be seen (like e-procurement from the 1990s). Other non-procurement work obviously includes the UNCITRAL's work in receivables assignment, secured transactions, IP security rights and registries, and secured transactions.

4. Get China on Board. Ensure China -- as the likely world leader in setting FinTech standards and applications for use in procurement at home and abroad -- participates in international fora setting FinTech standards and peer review. If we end up using Chinese technologies and procurement standards, ensure they respect the basics of our already developed procurement principles in procurements on our soil.

5. Shame and discourage awards to overly aggressive proprietary standards. FinTech projects should use open architectures as well as open platforms. Do not grandfather in proprietary standards even for market leading blockchain or virtual asset (token) service providers of FinTech services.

6. Leapfrog inefficient banking sectors. Many of the recommendations for domestic parties (above) will help encourage international public procurement. Having contracting authorities who can send directly (without the need for banks or even expensive administrative staff) payments via transparent ledgers can help lower costs and ensure project completion. FinTech can leapfrog/overtake the whole traditional "financial sector development" policies of the Bretton Woods institutions. 


\section{How Should Public Procurement Law Deal With FinTech? Bryane Michael, University of Hong Kong}

\section{Introduction}

Financial technology (alternatively FinTech or Fintech) has become one of the earliest buzzwords of the $21^{\text {st }}$ century. ${ }^{1}$ From threatening global banking to accomplishing the United Nations' Sustainable Development Goals, authors and academics of all stripes extol the promise of FinTech everywhere. ${ }^{2}$ The use of information technologies have undoubtedly rationalized business processes and lowered transactions costs around all kinds of finance. ${ }^{3}$ These technologies may even create, participate in, or otherwise contribute to 'ecosystems' which reorganize consumption, distribution and production patterns in particular sectors -- including in high-volume, low-margin retail finance. ${ }^{4}$ Yet, FinTech differs from simple e-finance in the convergence of a set of technologies like blockchains, distributed ledgers, smart contracts, and crypto-assets -- often used on a platform or in combination. Such combinations form synergies which some talk about as a FinTech ecosystem. ${ }^{5}$ If widely adopted, such FinTech (if the word can encompass all these technologies) threatens/promises to remove dramatically financial intermediaries from finance. ${ }^{6}$

Despite its economic importance, government procurement represents one of the most neglected areas of the FinTech craze. A few large banks and consulting firms have issued their own sales-dressed-as-analysis pieces online. These analyses look at how FinTech

\footnotetext{
${ }^{1}$ The press and others often use the word as a stand-in for any kind of innovation involving blockchains and new technologies involving money or finance. We address the difficulty in defining the word -- and offer our own working definition -- subsequently. For an independent take on the difficulty in defining and using this word, see Liudmila Zavolokina, Mateusz Dolata and Gerhard Schwabe, The FinTech Phenomenon: Antecedents of Financial Innovation Perceived by the Popular Press, Financial Innovation 2(16), 2016, available online.

${ }^{2}$ For one such view of FinTech as the cure-it-all for the modern era, see Juan Cortina Sergio Schmukler, The Fintech Revolution: A Threat to Global Banking?, World Bank Research \& Policy Brief No. 14, 2018, available online.

${ }^{3}$ Allen and his co-authors are just a few who illustrate the digital revolution's benefits for finance. See Franklin Allen, Xian Gu, and Julapa Jagtiani, A Survey of Fintech Research and Policy Discussion, Federal Reserve Bank of Philadelphia Working Paper 20-21, 2020, available online.

${ }^{4}$ The inclusion of millions or billions of individuals without bank/financial accounts represents an excellent side-benefit of the internet age. See Sofie Blakstad, Robert Allen, Ecosystem vs Egosystem and Revolution vs Evolution, In Sofie Blakstad and Robert Allen, FinTech Revolution: Universal Inclusion in the New Financial Ecosystem, 2020, available online.

${ }^{5}$ We will see later how many of FinTech's benefits in a procurement setting rely on such platform-based or ecosystem-based approaches. Policymakers seek to make public procurement more innovative by procuring such ecosystems and innovation directly. See Willem van Winden and Luís Carvalho, Intermediation in [the] Public Procurement of Innovation: How Amsterdam's Startup-in-Residence Programme Connects Startups to Urban Challenges, Research Policy 48(9), 2019, available online.

${ }^{6}$ Master Nakamoto said it best, as Bitcoin, "a purely peer-to-peer version of electronic cash would allow online payments to be sent directly from one party to another without going through a financial institution." See Satoshi Nakamoto, Bitcoin: A Peer-to-Peer Electronic Cash System, Self-Published White Paper, available online.
} 
will change and challenge public procurement. ${ }^{7}$ Instead of addressing the challenge directly, many government leaders have simply outsourced thinking about FinTech's role in public procurement to start-ups and others. These senior government officials thus hope that market actors will do all the FinTech development (and thinking about its regulation) for them. ${ }^{8}$ In the process, these officials leave it up to FinTech firms themselves to define how FinTech will change finance, government, and public procurement. ${ }^{9}$ Philosophers may encourage any move away from governmentprovisioned services as a win for humanitarian and social/economic rights. ${ }^{10}$ Yet, debating the legal issues after the market has already developed made such debates futile; as well as removes any possibility of creating markets which purely serve the public interest. $^{11}$

In this paper, I argue that governments -- and public procurement bodies in particular -should not leave FinTech regulation to FinTech companies and associated bodies themselves. Instead, public procurement bodies should participate in the broader debate about regulating Fintech applications and services. Such participation should support generally internationally accepted public procurement principles - in regulation and in deed. Without some reasoned form of legal coordination or control, the existing approach to supporting FinTech would likely lead to a free-for-all -- making public procurements more expensive, less transparent, and more politicized. In that world, payments do not pass from one supplier to the next smoothly, rights over assets and obligations in supply chains remain uncertain, and risks third party manipulation of FinTech-related information technology across the whole-of-government.

My thesis covers the following. The first part describes FinTech as the nexus of blockchains, distributed ledgers, smart contracts, and cryptographic assets. I describe how all these components could enter into a public procurement -- from start to finish. I also describe the benefits and risks posed by a system where FinTech applications operate in/with every stage of the public procurement process. I also describe how/why FinTech

\footnotetext{
${ }^{7}$ For one example, see Steve Cheng, Matthias Daub, Axel Domeyer, and Martin Lundqvist, Using Blockchain to Improve Data Management in the Public Sector, McKinsey Brief, 2020, available online. For a more direct promise of change, see GEP, The Future of Procurement Technology Portable, Powerful, Pivotal, GEP White Paper, 2020, available online.

${ }^{8}$ We will see many examples of the international organizations, national governments (especially central banks) and others tendering research projects which require bidders to find ways for FinTech to usefully serve the government and its public procurements.

${ }^{9}$ The European Banking Authority (EBA) Roadmap makes such a follow-the-follower approach evident. The Roadmap encourages plenty of monitoring and using best practice - but does little to organize a regulatory approach. Worse yet, the EBA -- like most regulators -- only involves financial counterparts (ignoring the vast swaths of organizations that deal in trade finance/credit, financial guarantees used in procurements by bidders and so forth). See EBA, THE EBA'S Fintech Roadmap: Conclusions from the Consultation on the EBA's Approach to Financial Technology, 2018, available online.

${ }^{10}$ See Kobina Hughes, Blockchain, The Greater Good, and Human and Civil Rights, Metaphilosophy 48(5), 2017, 654-665, available online.

${ }^{11}$ Many legal scholars have complained that the lack of considered legal thought during the Internet's development - and especially Google's rapid rise to dominance over Internet search - has led to a worse Internet and a worse Internet law. See Emre Bayamlioglu and Ronald Leenes, The 'Rule of Law' Implications of Data-Driven Decision-Making: A Techno-Regulatory Perspective, Law, Innovation and Technology 10(2), 295-313, 2018, available online.
} 
can help uphold procurement principles -- as well as the way these principles can and should guide the way we legislate and incentivize the use of FinTech applications in the service of public procurement.

The second section looks at the public procurement of FinTech. The section describes how governments procure FinTech services as a way of developing the very FinTech applications which might make for better, future public procurement. The public procurement of such FinTech services grapples with thorny legal issues - like whether the procurement a FinTech platform or ecosystem usable for future procurements violates the principles of non-discrimination, equal treatment, proportionality, transparency and other cherished procurement-related jurisprudence. Do FinTech services on computer networks represent services of a general economic interest, and thus fall outside of procurement rules like the European Union's rules? If governments end up seeking to provide these general services -- do they constitute the trade-distorting state aid that many states seek to avoid?

The third section describes the options for regulating FinTech's use in procurement. I show how national procurement agencies can (try to) procure a public procurement FinTech ecosystem through their own regulatory powers or by statute. I also show how a free-for-all procurement regime would result (and has already resulted) in an uncompetitive FinTech environment in certain jurisdictions. I also show why the decentralized approach to regulation based in supervisory technologies or regulatory technologies (SupTech and RegTech respectively) will not solve the many problems arising from laissez-faire regulation. I show how a national approach to regulating FinTech-enabled procurement solves the coordination failures and potentially bad investments of the contracting agent (CA)-centric 'let a thousand flowers bloom' approach.

The fourth section looks at FinTech's promise to revitalize international public procurement law. FinTech applications and their supporting law could offer a boost to cross-border procurements conducted under the WTO's General Procurement Agreement, the UNCITRAL Model Public Procurement Law, the rules used by multilateral development banks and others. Yet, the West needs to proactively put in place a level playing field across borders. With China's growing influence, in FinTech as well as cross-border procurement under its Belt and Road (and other) initiatives, an international free-for-all could appear just as readily as the free-for-all predicted at the national level. Yet, agreements like the General Agreement on the Trade in Services (GATS) -- and especially provisions dealing with freedom to offer financial services across borders -will likely shape cross-border FinTech in procurement far more than changes to the international procurement regime itself.

The final section concludes by arguing for a close reading of procurement laws now, keeping in mind the way FinTech will help finance procurements (and the FinTechrelated applications/assets being procured). The current FinTech procurement free-for-all risks spending too much public money on distorting markets at home and abroad. A coordinated set of national rules governing which FinTech tools contracting agencies 
(CAs) can or can not use - and how they may or may not use them - seems sensible. The international procurement-related treaties and soft law can also ensure that governments do not harmfully compete with each other. The result of such competition would result in an international free-for-all where FinTech stymies international payments. Given China's lead in FinTech and strong position in international procurement markets, other countries' regulators should think now about ways of ensuring that the international FinTech regime does not entrench China's relatively lax and self-serving procurement rules in global procurement law.

The reader should keep a few caveats in mind when reading this analysis. First, this paper looks at public procurement, ignoring many of the important aspects of FinTech and the procurement regulations of the private sector. ${ }^{12}$ Second, I address the topic from the FinTech optimist's point of view -- assuming that experts end up solving all the technical and other problems which might delay/stop FinTech from working 'as advertised' in the popular media. I take such an extreme view only to illustrate the general principles of using FinTech in public procurement more clearly. Such a view includes assuming the integrity, security and safety of such FinTech. I avoid discussing technical and related security issues, as such a discussion would offer little in the way of shedding light on procurement or finance. ${ }^{13}$ Third, I draw most of my examples from the EU Directives picking and choosing from other examples at-will. The Directives harmonize with international rules like the UNCITRAL Model Law on Public Procurement and thus many countries' laws. The United States (US) represents one jurisdiction where such an assumption falls flat. I avoid discussing US law or practice, given its complexity. ${ }^{14}$ Finally, I avoid talking about specific FinTech companies or platforms (like BitCoin, ScienceSoft, or AliPay). We wish to talk about general policy issues - rather than the specific and potentially ephemeral companies making news in any particular month or year.

\footnotetext{
${ }^{12}$ For readers unfamiliar with public procurement, see Abby Semple, A Practical Guide to Public Procurement, Oxford: OUP, 2015. See Prier, E. and McCue, C.P. The implications of a muddled definition of public procurement, Journal of Public Procurement 9(3/4): 326-370, 2009, available online. For those curious about the finance of such procurement, see Bernardo Nicoletti, Procurement Finance: The Digital Revolution in Commercial Banking, Palgrave, 2018.

${ }^{13}$ I accept that such security issues bedevil even simpler efforts toward digitizing procurement processes. For readers interested in some of the problems, see Ganesh Vaidyanathan, Sarv Devaraj and John D'Arcy, Does Security Impact E-procurement Performance? Testing a Model of Direct and Moderated Effects, Decision Sciences 43(3), 437-458, 2012, available online.

${ }^{14}$ Such a decision represents an unfortunate and unavoidable necessity. Unfortunate, as many of the most interesting FinTech-related developments come from the US. Moreover, Part 32 of the US Federal Acquisition Regulation presents the rules around procurement finance far more clearly and directly than those in similar EU law. Such well-defined regulations make the task of transitioning to new technologies easier. See K. Cory, C. Coggeshall, J. Coughlin, and C. Kreycik., Solar Photovoltaic Financing: Deployment by Federal Government Agencies, National Renewable Energy Lab Report NREL/TP-6A246397, 2009, available online.
} 


\section{Why FinTech for Public Procurement?}

\section{The Four Aspects of Our Working Definition of FinTech?}

Few can even agree on the working definition of FinTech -- much less discuss how such technology fits into financial service or public service provision. Authors like Schueffel trawl decades of the literature, finally concluding that, "Fintech is a new financial industry that applies technology to improve financial activities." ${ }^{15}$ Yet, what constitutes "financial activities"? For many, FinTech encompasses the automation of payment systems, the use of new payment means (like cryptocurrencies), new ways individuals and companies lend directly to each other on digital platforms, the offer of insurance in similar ways, and so forth. ${ }^{16}$ Behind most definitions lie the assumption that FinTech represents a complement or substitute to traditional financial services sectors. ${ }^{17}$

Those working in the public sector see FinTech as something far more important. The blockchains often associated with FinTech represent the potentially truly revolutionary aspect of FinTech. Such blockchains -- or chains of data which store information about various aspects of a transaction or interaction with such information -promise to rationalize public service provision. ${ }^{18}$ National Savings and Investment (NS\&I) -- a UK government service -- crows about FinTech's potential to revolutionize public service provision. ${ }^{19}$ Users of FinTech applications can use one-stop payment systems, have access to a range of financial information across ministries and agencies, and save, invest or transfer money electronically. ${ }^{20}$

For our purposes, "FinTech" refers to four aspects of the evolving and slowly condensing debate about the use of financial technologies. First, blockchains serve as the basis on which much of the FinTech literature is based. Such blockchains simply represent ledgers or 'strings' of information which can record anything --from citizens' health and

\footnotetext{
${ }^{15}$ If Schueffel provides a definition culled carefully from academia, Rupeika-Apoga and Thalassinos in particular, cover the definitions used in much of the international organisation and policy literature (ie nonacademic literature). See Patrick Schueffel, Taming the Beast: A Scientific Definition of Fintech, Journal of Innovation Management 4(4), 2016, 32-54, at 32, available online. See also Ramona Rupeika-Apoga and Eleftherios Thalassinos, Ideas for a Regulatory Definition of FinTech, International Journal of Economics and Business Administration 8(2), 2020: 136-154, available online.

${ }^{16}$ See Anjan Thakor, Fintech and Banking: What Do We Know?,Journal of Financial Intermediation 41, 2020, available online.

${ }^{17}$ See Rebel Cole, Douglas Cumming, and Jon Taylor, Does FinTech Compete with or Complement Bank Finance?, SSRN Working Paper 3302975, 2019, available online.

${ }^{18}$ The reader interested in learning about the links between blockchains and finance can sit the MIT online course on the topic. See Gary Gensler, Blockchain and Money, MIT Course Openware, 2018, available online.

${ }^{19}$ For example, see Unnamed Author, Public Finances: The Power of Fintech in Service Delivery, Global Government Forum Website, available online.

${ }^{20}$ Indeed, the NS\&I website totes its saving and investing functions. The state-owned NS\&I -- formerly the UK's Post Office Savings Bank -- encourages UK citizens to save and help finance the UK's debt. Such a prized position among financial institutions gives its Fintech offerings a potential advantage, as discussed later in this paper.
} 
employment history -- to their financial transactions. ${ }^{21}$ Their potential has encouraged authors from the European Commission and elsewhere to reorient public services around blockchains. ${ }^{22}$ Such blockchains have their inevitable uses in public procurement as well. ${ }^{23}$ Second, if users or interested third-parties share these blockchains and their information, they represent distributed ledgers. Blockchains simply represent one kind of distributed ledger - and FinTech can involve more than one type of such distributed ledger technology. ${ }^{24}$ Such distributed ledgers thus hope to complete the idea of the paperless office started in the e-procurement days -- with copies of forms or other information going out and coming in digitally... as needed. ${ }^{25}$

The final two of the four FinTech aspects represent the most exciting and challenging. Third, the aforementioned blockchains may include smart contracts. Such smart contracts make the recording, or any transaction on the blockchain, contingent on some event which can be automatically and digitally monitored. For example, such smart contracts may ensure compliance with tendering terms, automatically assign evaluation scores and even allow consortia to engage in project planning with much of the monitoring and verification done electronically. ${ }^{26}$ Fourth, and finally, the creation, transfer and digital securitization of assets and liabilities allow cryptographically secured assets -- or tokenization -- to replace ownership stakes, debts, or any other kind of value previously noted on paper (like deeds, IOUs and even paper money itself). ${ }^{27}$ Any asset,

\footnotetext{
${ }^{21}$ For more on the technical aspects of blockchains -- like their security or confidentiality -- in a public sector context, see Steve Cheng, Matthias Daub, Axel Domeyer, and Martin Lundqvist, Using Blockchain to Improve Data Management in the Public Sector, McKinsey Brief, available online.

${ }^{22}$ See David Allessie, Maciej Sobolewski and Lorenzino Vaccari, Blockchain for Digital Government: An Assessment of Pioneering Implementations [sic] in Public Services, European Commission Joint Research Centre Working Paper 115049, 2019, available online.

${ }^{23}$ Somasundaram and Hasan provide an excellent overview of electronic procurement and the way blockchains will likely change such procurement. See Ramanathan Somasundaram and Quamrul Hasan, Development of a Global e-Government Procurement Architecture using Blockchain Technology, Asian Development Bank Technical Report 47192-001, 2018, available online.

${ }^{24}$ For authors like Mainelli and Smith, such ledgers can contain know-your-customer information, insurance, or any other information the sharer sees fit to share. These attributes make distributed ledgers perfect for recording transactions. Sanchez, though, provides readers with a particularly disheartening view of distributed ledger technologies in government (public) procurement. See Michael Mainelli and Mike Smith, Sharing Ledgers for Sharing Economies: An Exploration of Mutual Distributed Ledgers (aka Blockchain Technology), Journal of Financial Perspectives 3(3), 2015, available online. See also Sergi Sanchez, The Implementation of Decentralised Ledger Technologies for Public Procurement: Blockchain Based Smart Public Contract, European Procurement \& Public Private Partnership Law Review 14, 180, 2019, available online.

${ }^{25}$ See Damle Pramod, Benjamin Zachariah, Tina Salim, Moving Beyond Paperwork: Blockchain in Public Sector, Telecom Business Review 12(1), 2019, 50-55, available online.

${ }^{26}$ Debono provides more on these contracts in a procurement setting. While these possibilities exist -authors like Allam have raised suspicions about all these capabilities, given smart contracting is still underdeveloped and an untested technology. See Pauline Debono, Transforming Public Procurement Contracts into Smart Contracts, International Journal of Information Technology Project Management 10(2), 2019, available online. See also Zaheer Allam, On Smart Contracts and Organisational Performance: A Review of Smart Contracts through the Blockchain Technology, Review of Economic and Business Studies 11(2), 2019, available online.

${ }^{27}$ Few jurisdictions have tried to define -- much less regulate -- these financial products. For an example of a jurisdiction currently moving forward, see Hui Huang, Demin Yang, and Fai-Yang Loo, The
} 
commodity, or real world object can have a digital claim attached to it -- making the transfer of ownership or other rights and obligations easier. ${ }^{28}$ Owners can even tokenize commodities, as long as they can be tagged with some kind of identifier. ${ }^{29}$

All together -- blockchains, distributed ledgers, smart contracts and tokenization -represent the applications analyzed under the rubrique of FinTech. ${ }^{30}$ FinTech-enabled public procurement refers to the use of these technologies when dealing with the transfer of information. Such information may include information about goods and services themselves, and not exclusively about the monetary movements underlying a public procurement. ${ }^{31}$

\section{FinTech's Application to Public Procurement}

Many authors have claimed that the FinTech-related technologies discussed above can help transform public procurement. ${ }^{32}$ For Maltaverne, such transformations include the streamlining of procurements, making them more transparent, and reducing broader risks to the entire procurement sector. ${ }^{33}$ Headlines like those announced by FinTech Futures portend promising collaborations between FinTechs like BlueVine (a finance provider to SMEs delivering on government procurements) and GovQuote (a US platform listing new procurements opportunities). ${ }^{34}$ The Seoul district has reportedly used blockchains for public procurement activities. ${ }^{35}$ Van der Peijl and his team have noted how blockchains have helped organisations like the US Department of Human Health match thousands of payers and service providers -- ensuring that only authorized payees receive invoices, as well as the correct and almost instantaneous processing of payments. ${ }^{36}$

Development and Regulation of Cryptoassets: Hong Kong Experiences and a Comparative Analysis, European Business Organization Law Review 21, 319-347, 2020, available online.

${ }^{28}$ See Iota Kaousar Nassr, The Tokenisation of Assets and Potential Implications for Financial Markets, OECD, 2020, available online.

${ }^{29}$ See Charles Okaformbah, Blockchain Tokenisation in a B2B Trade Finance Supply-Chain Sector, Medium, 2018, available online.

${ }^{30}$ Many miss tokenization as a part of the larger transformation of the public sector. For one example, see Jason Killmeyer, Mark White and Bruce Chew, Will Blockchain Transform the Public Sector?, Deloitte

Press, 2017, available online.

${ }^{31}$ See also Kishor Vaidya and John Campbell, Multidisciplinary Approach to Defining Public E-

Procurement and Evaluating its Impact on Procurement Efficiency, Information Systems Frontiers 18: 333348, 2016, available online.

${ }^{32}$ Many advocates for using FinTech in procurement -- and particularly in settling accounts between the range of participants in such a procurement -- come from non-academic sources. See Alex Hales, How Blockchain is Transforming the Future of Finance? PaymentsJournal, 2019, available online.

${ }^{33}$ Bertrand Maltaverne, What Can Blockchain Do for Public Procurement?, Public Spend Forum, 2018, available online.

${ }^{34}$ See FinTech Futures, BlueVine and GovQuote team up to fund SMEs, FinTech Futures Web Page, 2019, available online.

${ }^{35}$ Ledger Insights, Seoul District Using Blockchain for Public Procurement, 2019, available online.

${ }^{36}$ Sebastiaan van der Peijl, George O’Neill, Laura Doumbouya, Victoria Howlett, and Joao de Almeida, Study on the Up-Take of Emerging Technologies in Public Procurement, Framework Contract DI/07624ABC IV Lot 3 Final Report, 2020, at p. 109. 
How might FinTech technologies enter at each stage of the procurement process? ${ }^{37}$ Figure 1 shows how FinTech might change aspects of public procurement. ${ }^{38}$ I can not describe every single point. ${ }^{39}$ However, some issues stand out more than others. For example, FinTech can encourage the collection of specific taxes or obligatory financial contributions toward some social/public service. For example, campaigns by groups like FinTech4Good promise/threaten to change the business improvement district (BID) and other 'voluntary' taxes and contributions made by communities. ${ }^{40}$ These taxpayers -- in theory and especially if paid with a native blockchain currency like Bitcoin -- could actually trace their coin to the final product or service via a blockchain.

\section{Figure 1: FinTech's Likely Effects on Public Procurement*}

\begin{tabular}{|c|c|c|c|}
\hline $\begin{array}{l}\text { budgeting } \\
\text { the procurement }\end{array}$ & $\begin{array}{l}\text { pre-competition } \\
\text { stage }\end{array}$ & $\begin{array}{l}\text { bid } \\
\text { preparation }\end{array}$ & $\begin{array}{l}\text { project } \\
\text { delivery }\end{array}$ \\
\hline Budget Law & PSD, arts 13,14 & PSD arts. $26-32$ & PSD arts. $70-73$ \\
\hline $\begin{array}{l}\text { 1. tying taxes to the } \\
\text { specific tenders with } \\
\text { unique IDs } \\
\text { 2. dist. ledger } \\
\text { appropriations, transfers, } \\
\text { and distributions } \\
\text { 3. portal showing whole- } \\
\text { of-government planned } \\
\text { activities } \\
\text { 4. disbursement only if } \\
\text { smart contract conditions } \\
\text { met (like a team } \\
\text { organized), } \\
\text { 5. automatic allocation of } \\
\text { budget/man-hours to draft } \\
\text { tenders, publish them, } \\
\text { and so forth. } \\
\text { 7. appropriating for or } \\
\text { crowding-in co- } \\
\text { investments from outside } \\
\text { 8. real-time audit of } \\
\text { finance, asset and (if } \\
\text { necessary) liability use. }\end{array}$ & $\begin{array}{l}\text { 1. unique coin venture } \\
\text { capital funding } \\
\text { 2. deposits auto } \\
\text { given/received } \\
\text { given performance } \\
\text { targets } \\
\text { 3. auto payment transfers } \\
\text { between consortia } \\
\text { members } \\
\text { 4. auto payment transfers } \\
\text { between CAs calling for } \\
\text { tenders } \\
\text { 5. electronic payment of } \\
\text { contractors, staff and } \\
\text { others (in tokens if } \\
\text { accepted) } \\
6 . \text { FinTech and portal } \\
\text { integration to allow } \\
\text { querying } \\
\text { 7. auto querying b/t } \\
\text { consortium members' } \\
\text { accounts to ensure } \\
\text { solvency and liquidity. } \\
\text { 8. encourage SMEs }\end{array}$ & $\begin{array}{l}\text { 1. budgeting } \\
\text { resources to } \\
\text { prepare bid } \\
\text { 2. crowdsourced } \\
\text { debt (liquidity } \\
\text { management) } \\
\text { 3. online platforms } \\
\text { 4. pre-authorized } \\
\text { payments for } \\
\text { achieving various } \\
\text { planning objectives } \\
\text { 5. cash } \\
\text { management to } \\
\text { maximize yield } \\
\text { 6. attestation of } \\
\text { solvency/liquidity } \\
\text { for competence } \\
\text { 7. specific funds } \\
\text { tied to specific } \\
\text { assets and/or } \\
\text { outcomes in the } \\
\text { project plan } \\
\text { 8. real-time audit } \\
\text { 9. bank/funder real- }\end{array}$ & $\begin{array}{l}\text { 1. drawing on and } \\
\text { disbursement of } \\
\text { funds on just-in- } \\
\text { time basis } \\
\text { 2. government, } \\
\text { partners and even } \\
\text { public oversight of } \\
\text { spending and } \\
\text { results } \\
\text { 3. use of FinTech } \\
\text { providers in case of } \\
\text { liquidity shortfalls } \\
\text { and other problems } \\
\text { 4. transfer of funds } \\
\text { across partners and } \\
\text { contractors } \\
\text { immediately and } \\
\text { paperlessly } \\
\text { 5. encourage real- } \\
\text { time haggling on } \\
\text { price and terms - } \\
\text { building vibrant } \\
\text { markets. }\end{array}$ \\
\hline
\end{tabular}

\footnotetext{
${ }^{37}$ As of 2021, Nicoletti represents an uncontested expert in the potential use of FinTech in public procurement. From understanding the procurement cycle to the ways flexible finance can help small and medium enterprises participate in tenders, Nicoletti provides a one-stop-shop for explaining many of the changes we can only describe here in passing. See Bernardo Nicoletti, Procurement Finance: The Digital Revolution in Commercial Banking, Palgrave, 2018.

${ }^{38}$ Oueid provides an excellent overview of the types of finance underpinning procurements (in her case, the procurement of microgrids). See Rima Oueid, Microgrid Finance, Revenue, and Regulation Considerations, The Electricity Journal 32(5), 2019, pp. 2-9, available online.

${ }^{39}$ For details, especially details related to the technical aspects of combining blockchains, smart contracts and procurement, see Freya Sheer Hardwick, Raja Naeem Akram, and Konstantinos Markantona, The Fair and Transparent Blockchain based Tendering Framework - A Step Towards Open Governance, Arxiv Working Paper 1805.05844, 2018, available online.

${ }^{40}$ See FinTech for Good, 2021, available at: http://www.fintechforgood.com/
} 


\begin{tabular}{|l|l|l|l|} 
& $\begin{array}{l}\text { through automated bid } \\
\text { and project coordination }\end{array}$ & $\begin{array}{l}\text { time monitoring of } \\
\text { funds' use }\end{array}$ & \\
\hline
\end{tabular}

* PSD refers to the EU Public Sector Directive 2014/24

Distributed ledger technologies will not drive government budgeting any time soon. Yet, some scholars see a day where blockchains might serve as the medium on which budget debates, proposals, amendments, adoptions and even in-year tracking of appropriations versus spending can all take place. ${ }^{41}$ Some scholars have already mapped out how such new budget processes could align with new blockchain-centred procurement methods. ${ }^{42}$

To take another example from Figure 1, FinTech offers to facilitate financial transactions within and between bidding consortia and other members. In the past, traditional supply professionals had to use cumbersome techniques -- like creating special purpose entities and joint venture legal structures. ${ }^{43}$ With blockchains, bidders can post transactions and instructions contingent on such finance, as well as can create communities which simply net out transactions between themselves or with non-group members. Such groupings can take the form of decentralized autonomous organizations (discussed later) or permissioned blockchains. ${ }^{44}$

FinTech-enabled procurement promises to reduce transactions costs in several ways. First, because finance usually 'travels' the opposite direction as the real-world flows of goods and services such finance pays for, such blockchains can hold both the financial and logistics information of any transaction. ${ }^{45}$ Second, smart contracts can calculate the most economically advantageous offer using formulae provided to bidders and which contracting authorities must use anyway. ${ }^{46}$ To the extent contracting authorities use lifetime or other costing, public blockchain records of these costs in other awards would help set a baseline for determining such awards in the future. ${ }^{47}$ Third, ownership or possession can be tokenized - allowing for the easy and secure holding or transfer of these tokenized assets, liabilities, incomes, or expenses across the wide range of procurement stakeholders. $^{48}$

\footnotetext{
${ }^{41}$ For example, see Kai Schmidt and Philipp Sandner, Solving Challenges in Developing Countries with Blockchain Technology, Frankfurt School Blockchain Center Working Paper, 2017, at p. 9, available online.

${ }^{42}$ Ironically, some of the best laid plans come from the countries least able to carry them out. See Temofe Akaba, Alex Norta, Chibuzor Udokwu and Dirk Draheim, A Framework for the Adoption of BlockchainBased e-Procurement Systems in the Public Sector: A Case Study of Nigeria, In Marie Hattingh, Machdel Matthee, Hanlie Smuts, Ilias Pappas, Yogesh Dwivedi, and Matti Mantymaki, Responsible Design, Implementation and Use of Information and Communication Technology, 2020, available online.

${ }^{43}$ Adrian Smith, Consortium and Joint Venture Bidding, In Estimating, Tendering and Bidding for Construction, Springer, 1995, at 212-226, available online.

${ }^{44}$ Deshpande and co-authors describe the underlying technologies needed for such an organization. See J. Deshpande, M. Gowda, M. Dixit, M. Khubbar, B. Jayasri and S. Lokesh, Permissioned Blockchain Based Public Procurement Systems, Journal of Physics Conference Series 1706, 2020, available online.

${ }^{45}$ Colman McMahon, The Blockchain \& Public Procurement: Reducing Corruption and Increasing Efficiency, 2016, available online.

${ }^{46}$ Public Sector Directive at art 35(6), art. 56.1 para 2, and especially the whole of art. 67 (award of contract). See Public Sector Directive 2014/24, hereinafter 'PSD'.

${ }^{47}$ PSD at art. 68.

${ }^{48}$ For a fuller description, see Aryo Dhaneswara, Tokenizing Public Procurement, 2020, available online.
} 
Certain types and aspects of procurement seem more amenable to FinTech-enabled public procurement than others. Framework agreements, dynamic purchasing systems, electronic auctions and catalogues have the kind of repeat purchasing involving several pre-qualified parties -- and are thus amenable to FinTech-enabled procurement. ${ }^{49}$ The division of large procurements into lots also encourages the kinds of linked records which FinTech technologies encourage. ${ }^{50}$ Even documents required for first stage qualification - like the European Single Procurement Document -- have amend-only characteristics (like previous jobs) which seem amenable to recording on blockchains. ${ }^{51}$ Smart contract technologies can automatically screen tenders for compliance with award criteria, flag abnormally low tenders and even ensure compliance with various rules (such as criteria for the award of social and similar services). ${ }^{52}$

FinTech will likely have the largest impact on non-standard public contracts. These include utility, concessions, state aid, block grant, and other contracts where winning bidders receive an 'advantage. ${ }^{53}$ As shown by the red-coloured actors in Figure 2, blockchains can keep tabs on these recipients of implicit or explicit subsidies - ensuring they do not excessively abuse the market power which their advantage confers to them.. While the Transport Regulation describes public networks in public passenger transport services, these economics apply to any public network. ${ }^{54}$ If the public procurement process handles any public service auctioned and resulting in a public service contract (or similar agreement), a public record on something like a public blockchain should contain non-commercially and non private elements of that award. ${ }^{55}$

\footnotetext{
${ }^{49}$ Specifically the procedures defined in PSD arts. 33-36.

${ }^{50}$ The use of lots - particularly to encourage participation by small and medium enterprises (SMEs) -represents a topic which we address later in this paper. See PSD at art. 46.

${ }^{51}$ See PSD at art. 59 (and section 3 in general for choice of vendors). The introduction of electronic procedures took more than 6 years to accomplish among EU member states. Whether these governments have the appetite to undergo another round of reform remains to be seen. See Judit Glavanits, The Future of Public Procurement: Innovation and Blockchain Technology, In Judit Glavantis and Peter Balint Kiraly (Eds), Law 4.0 - Challenges of the Digital Age, Szechenyi Istvan University, 2019, available online.

${ }^{52}$ See PSD at arts. 67, 69, and 74.

${ }^{53}$ The Utilities Directive, Transport Regulation as well as the various rules on state aid describe such advantage in greater detail. For the definition of advantage, and the other legal aspects of such advantage, see Phedon Nicolaides, State Aid, Advantage and Competitive Selection, European State Aid Law Quarterly 9(1), 65-78, 2010, available online.

${ }^{54}$ See Regulation (EC) No 1370/2007 on public passenger transport services by rail and by road, available online.

${ }^{55}$ Such a situation seems a long way away - as releasing/publicizing even paper public service contracts requires much effort in the UK. See Joshua Pritchard and Rose Lasko-Skinner, Please Procure Responsibly The State of Public Service Commissioning, Reform Procurement Working Paper, 2019, available online.
} 


\section{Figure 2: The Decentralized Autonomous Groups Making} Up a Public Procurement and the Distribution of "Advantage"

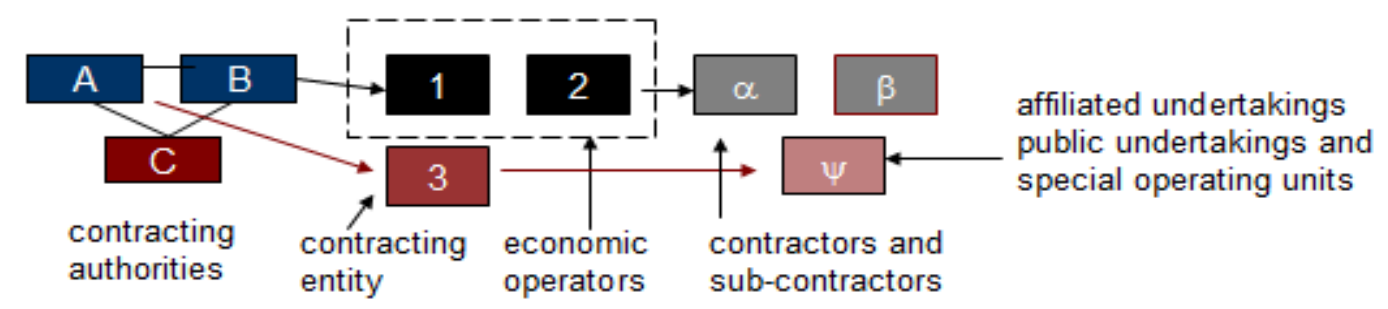

Thin k of 'advantage' as an amount of aid, market rents derived from market power conferred by the utility or government authority, or a subsidy. Blockchains can help keep track of public spending (for entities in black and gray). But the real advantage is to track the 'advantage' (value of the rents) being transferred around the virtual procurement organization.

FinTech will likely affect those areas of public procurement which benefit most from public-private partnerships of any kind. Figure 3 shows the ways FinTech might require changes to the standard procurement procedures dealing with such partnerships. For example, the UK's Private Finance Initiative encouraged the private funding of projects ultimately going out in/under public tender. ${ }^{56}$

\section{Figure 3: FinTech Likely to Affect the Public-Private Nexus in Public Procurement}

\section{\begin{tabular}{|l|l|l} 
public-private partnerships & joint-ownership models & cross-border
\end{tabular}}

1. involving public in budgeting decision

2. encourage special district taxes

to pay for specific public goods

3. transfer of government money to public to incentive certain behaviours

4. payments to government on smart contract terms

5. encourage postal banking and small scale financial inclusion (savings)

6. specialized FinTech savings, investment or transfer (like agricultural banks of old days), 7. real-time monitoring of spending, revenue (if applicable), responsible persons.

8. smart purchases contingent on other partners' performance on commitments

9. smart contingent contracts in case of unforeseen events

\section{procurement}

1. allows public to 'own' (outright or have mentionable rights in public goods/services)

2. help raise money for buildoperate-transfer to communities 3. raise money for upkeep if government unable/ unwilling 4. securitization of public assets or even use-rights

5. direct and easy bank monitoring

6. direct savings to particular (exact) outputs

7. e-transfers and public/visible proof
1. Helps identify and facilitates valuation of assets (procurements) abroad 2. International budgetary transfers (govt-to-govt) with or without using the banking system

3. facilitates timely payments between foreign (and local) governments and companies

4. facilitates timely and accurate payments between companies across borders 5. provides basis for payment methods bypassing traditional currencies 6. encourages inter-bank transfers, the verification of standing, and competence 7. encourages oversight of procurements done abroad and foreigners foreign

\footnotetext{
${ }^{56}$ See Akintola Akintoye, Cliff Hardcastle, Matthias Beck, Ezekiel Chinyio \& Darinka Asenova, Achieving Best Value in Private Finance Initiative Project Procurement, Construction Management and Economics 21(5), 2003, at 461-470, 2003, available online.
} 
Most importantly, FinTech-enabled public procurement should disintermediate finance and procurement, as separate functions. ${ }^{57}$ Traditional lenders must underwrite bidders' bids, provide working capital (as part of winners' cash management), provide deposits and other guarantees, as well as other funds in case of problems. For Nicoletti, such disintermediation between his 4 Ps -- proprietors, providers, producers, and purchasersmeans that from conception, owners and producers can extend credit personally... without relying on these formerly third-party funders. Instead, procurement moves to electronic platforms or ecosystems. ${ }^{58}$

FinTech-enabled procurement also promises to make procurement policy oversight easier. Public blockchains make data available to procurement agencies and officials (as well as financial regulators and the public). These groups can observe trade settlement, loan and finance flows, insurance terms, frequencies, and pay-outs as well as custodial/ownership chains and 'transactions costs' (like port fees, charges for consignments, tolls and other costs) to the extent privacy rules allow. ${ }^{59}$

Is FinTech-enabled public procurement legal? In the EU's Public Sector Directive for example, art 2(18) clearly applies to material on blockchains as 'written' and article 2(19) allows for such "electronic means". Such law clearly allows for e-procurement, as EU policymakers put in place multi-year programmes to digitize various aspects of procurement, from e-certis to e-invoicing. Yet, challenges remain. Doubts and legal problems with using FinTech in public procurement abound. ${ }^{60}$ Technically, the Directives do not mention FinTech as a form of demonstrating "economic and financial standing," thus leaving many applications in a state of uncertainty. ${ }^{61}$ The recent United Kingdom (UK) Green Paper tells just how FinTech can help share bidder information, ensure

\footnotetext{
${ }^{57}$ Nicoletti provides the motivation for much of this section - and for much thinking about FinTech in public procurement. See Bernardo Nicoletti, Fintech and Procurement Finance 4.0, In B. Nicoletti, Procurement Finance, Springer, 2018, available online.

${ }^{58}$ For example, see Edward Frazelle, Supply Chain Strategy: Unleash the Power of Business Integration to Maximize Financial, Service, and Operations Performance, McGraw-Hill, 2018. No one argues for a revolutionary view more than Nicoletti. See Bernardo Nicoletti, The Future: Procurement 4.0, In Bernardo Nicoletti, Agile Procurement: Designing and Implementing a Digital Transformation, Springer, 2017, available online.

${ }^{59} \mathrm{McMahon}$ stresses that financial regulators would also have access to such information. Other authors like Sanchez-Graells, though, see such real-time market oversight as a white elephant. He claims - with convincing evidence - that blockchains and the other technologies enabling the use of FinTech would do little to allow regulatory authorities to engage in market oversight. See Colman McMahon, Blockchain \& Public Procurement: Reducing Corruption, Increasing Efficiency, 2016, available online. See also Albert Sanchez-Graells, Data-Driven and Digital Procurement Governance: Revisiting Two Well-Known Elephant Tales, SSRN Working Paper, 2019, available online.

${ }^{60}$ For details, see Pawel Nowicki, Deus Ex Machina?: Some Remarks on Public Procurement in the Second Machine Age, European Procurement \& Public Private Partnership Law Review 15, 53, 2020, available online.

${ }^{61}$ The PSD for example, sets out the acceptable means of showing such standing. All three criteria refer to statements generated from traditional banking intermediaries. See PSD, at Annex XII.
} 
bidders' qualification, financial capacity, and so forth. But the Paper does not mention FinTech. $^{62}$

\section{The Promises and Pitfalls of FinTech in Public Procurement}

FinTech can help make procurement cheaper, faster, and better serve the public interest. FinTech lowers the cost of procurement-related finance by disciplining or eliminating financial intermediaries in the procurement process. Especially in under-developed economies, eliminating financial intermediaries -- rather than trying to develop them first -- may lead to cheaper tenders. ${ }^{63}$ Avoiding such financial intermediaries may save bidders up to $10 \%$ or more on the cost of their capital via inefficient national financial services firms. ${ }^{64}$ For example, if a community wants a bridge, the bridge users themselves could pledge the electronic funds to the government entity or even particular bidders. ${ }^{65}$ Clearly, such direct payments would be cheaper than the 'procurement' of microfinance providers -- in which financial institutions compete over the right to offer microloans to start-ups. ${ }^{66}$ Similarly, just-in-time funding could disburse funding based on smart contract rules -- reducing the need for reserve funding. Using cryptographic media of exchange and digital, cryptographically-secured securitized assets could certainly help reduce the need for such intermediaries' services, ranging from custodianship (of assets) to simple funds transfers.

FinTech-enabled technologies could lead - in the longer term -- toward a common procurement platform. On such a platform, bidders could seek crowdfunded short-term payables, trade finance, or even cross-border deposits or cross exchange rate funded ancillary services which could help reduce costs for cross border procurement. Such a common platform could also/even encourage third-party oversight - ensuring delivery ontime and on-budget. ${ }^{67}$ Having an intermediary -- whether championed by the private or public sector - could help ensure an efficient procurement ecosystem. ${ }^{68}$

\footnotetext{
${ }^{62}$ See UK Cabinet Office, Transforming Public Procurement, 2020, available online.

${ }^{63}$ In the 2010s, World Bank officials had heavily pushed for 'financial sector development' as an engine of growth. Later, they realized that too much development led to financial instability - rather than better governance or economic performance. See Adolfo Barajas, Thorsten Beck, Era Dabla-Norris, and Reza Yousefi, Too Cold, Too Hot, or Just Right? Assessing Financial Sector Development Across the Globe, International Monetary Fund Working Paper 13/81, 2013, available online.

${ }^{64}$ See Pietro Calice and Nan Zhou, Benchmarking Costs of Financial Intermediation around the World, World Bank, available online.

${ }^{65}$ For a discussion, see Katrin Tinn, Distributed Ledger Technologies and Start-Up Financing, In Antonio Fatas (Ed.), The Economics of Fintech and Digital Currencies, p. 15, 2019, available online.

${ }^{66}$ See Unnamed author, Fund of Funds, FMFIB Launched a Public Procurement Procedure for Selection of Financial Intermediaries for Granting Microloans in the Social and Employment Fields, 2017, available online.

${ }^{67}$ In the US SmartProcure represents a procurement intelligence platform which provides historical purchasing data which procuring officials and others can use to lower costs and procure better quality goods and services. See GovTech: The Power to Transform Public Services in the UK, PWC Working Paper, 2016, at p. 9, available online.

68 Jakob Edler and Jillian Yeow, Connecting Demand and Supply: The Role of Intermediation in Public Procurement of Innovation, Research Policy 45(2), 2016, pp 414-426, available online.
} 
FinTech-enabled procurement would reduce simple document and processing costs. Public procurement, at present, represents a costly and error-prone endeavour. ${ }^{69}$ The extension of e-procurement, to standardized smart contracts and documents widely visible by a number of parties, can help reduce errors in offers (such as those mistyped or indicating incorrect amounts). Such visibility can also speed up payment processing, reduce processing errors. FinTech technologies can also better handle the large-scale, ever-changing structures of consortia, their suppliers, and their related parties (as shown in Figure 2 earlier). ${ }^{70}$ Even in World Bank procurements, having 4 different oversight bodies has failed to stop poor procurement practices. ${ }^{71}$ Procurement-related FinTech applications could built-in automated checks during project procurement and better eauction facilities. ${ }^{72}$ Smart contracts can also better keep track of the ancillary aspects of a bid -- such as energy or environmental laws governing the way the winning bidder(s) structure and execute their project. Large works contracts or utilities often need to comply with thousands of regulations -- from national environmental laws to local setback rules for building fences.

In line with EU and other countries' procurement policy objectives, FinTech-enabled procurement could increase SMEs' participation in public tendering. EU public procurement policy - and thus law - has long promoted SMEs' participation in the EU procurement ecosystem. Yet, numerous studies show the difficulties these SMEs have had. ${ }^{73}$ SMEs can not compete because of a lack of access to finance (among other reasons).$^{74}$ Many studies thus find that alternative methods of finance would make SMEs potentially more competitive. ${ }^{75}$ Whether as a decentralized or centralized system, various

\footnotetext{
${ }^{69}$ Literally thousands of articles describe poor public procurement practice in almost any country. Even the reader uninitiated in smart contracts can not help see that automating much of the procurement process would eliminate much of the woe described by these authors. See Laura Carpineti, Gustavo Piga, and Matteo Zanza, The Variety of Procurement Practice: Evidence from Public Procurement, In Nicola Dimitri, Gustavo Piga and Giancarlo Spagnolo, Handbook of Procurement, Cambridge, 2006, available online.

${ }^{70}$ Yet, procurement authorities would need to rely on the same inefficient procuring officials to move toward FinTech-enabled procurement, making the transition so much harder. For this warning, see Darya Davtyan-Davydova, Marat Martirosyan, Alexander Bortenev and Olga Sergacheva, Implementation and Realization of Technologies to Distributed Registers (Blockchain) and Smart-Contracts in Public Purchases, In Competitive Russia: Foresight Model of Economic and Legal Development in the Digital Age, available online. See also Sergi Sanchez, The Implementation of Decentralised Ledger Technologies for Public Procurement: Blockchain Based Smart Public Contract, European Procurement and Public Private Partnership Law Review 14, 2019, p. 180,, available online.

${ }^{71}$ These four agencies include World Bank staff, the country office, the procurement agency and the entity managing the project. See IEG, The World Bank and Public Procurement-An Independent Evaluation Volume II: Achieving Development Effectiveness through Procurement in Bank Financial Assistance, 2014, available online.

${ }^{72}$ Srinivas Yanamandra, Leveraging Fintech to Enhance Integrity in Public Finance, OECD On The Level, 2019, available online.

${ }^{73}$ Anthony Flynn and Paul Davis, The Rhetoric and Reality of SME-Friendly Procurement, Public Money and Management 35(2), 2015, available online. See also Anthony Flynn, Investigating the Implementation of SME-Friendly Policy in Public Procurement, Policy Studies 39(4), pp. 422-443, 2018, available online.

${ }^{74}$ For evidence, see Alessandro Ancarani, Carmela Di Mauro, Tara Hartley and Tunde Tátrai, A Comparative Analysis of SME Friendly Public Procurement: Results from Canada, Hungary and Italy, International Journal of Public Administration 42(13), pp. 1106-1121, 2019, available online.

${ }^{75}$ Le-rong Lu, Promoting SME Finance in the Context of the Fintech Revolution: A Case Study of the UK's Practice and Regulation, Banking and Finance Law Review 33(3), pp. 317-343, 2018, available online.
} 
alternative financing forms under the Fintech rubrique (like crowdfunding) could offer SMEs a way to compete for tenders with larger bidders. ${ }^{76}$ Some evidence already exists suggesting that FinTechs in China may make SME finance easier to obtain. ${ }^{77}$ Especially in international trade, FinTech could help SMEs obtain finance without costly third-party finance. $^{78}$

Fighting corruption represents one of the main motivations and areas where FinTech pilots have received the most attention. Some examples include the Brazilian National Development Bank's loan for tokenization to "facilitate anti-corruption initiatives in project lending", the Shenzhen Provincial Government's blockchainisation of tax invoices (to prevent fraudulent reimbursements), and a supposedly tamper-proof land registry in Andhra Pradesh. ${ }^{79}$ The World Economic Forum has made much ado about a study about a project aiming to track school lunches in Medellin (Colombia). ${ }^{80}$ FinTech also facilitates anti-corruption investigations -- as artificial intelligence can sift through big data, applying advanced analytics, and machine learning algorithms to find fraud, corruption and other forms of malfeasance. Cronyism and the abuse of dominant positions held by large-integrated financial-industrial groups become harder with more transparent tendering and contract performance. ${ }^{81}$ When bidders -- or anyone -- can become their own bank, the potential for gain as well as for the tracking of fraud and the misappropriation of funds increases. ${ }^{82}$

Such facilities would ease the recording and transfer/trade of government assets (many countries still do not have asset registers, much less any estimate of the value of those assets). ${ }^{83}$ Digital tokens and electronic commitment/disbursement records held in real time also facilitate project monitoring. Tokenised lending, distributed ledgers (like Hyperledger Fabric), and mobile applications thus give parties to procurement contracts - as well as citizens and other concerned third parties -- greater access to information. Even parties far away from the relevant municipality or administrative region can obtain this information.

\footnotetext{
${ }^{76}$ For examples, see Mark Fenwick and Joseph McCahery, Fintech and the Financing of Entrepreneurs: From Crowdfunding to Marketplace Lending, European Corporate Governance Institute Law Working Paper No. 369/2017, 2017, available online.

77 Tian-xiang Sheng, The Effect of Fintech on Banks' Credit Provision to SMEs: Evidence from China Finance Research Letters, 2021, available online.

${ }^{78}$ Xiao-yu Wang and Fa-sheng Xu, A Theory of FinTech and Trade Finance, SSRN Working Paper 3777250, 2021, available online.

${ }^{79}$ For all these examples, see Srinivas Yanamandra, Leveraging Fintech to Enhance Integrity in Public Finance, OECD On The Level, 2019, available online.

${ }^{80}$ Ashley Lannquist and Rachel Raycraft, Exploring Blockchain Technology for Government Transparency: Blockchain-Based Public Procurement to Reduce Corruption, World Economic Forum Working Paper, 2020, available online.

${ }^{81}$ Jeremy Kidd, FinTech: Antidote to Rent-Seeking, Chicago-Kent Law Review 93, 2018, p. 165, available online.

${ }_{82}$ Michael Nwogugu, The Case Of Apple, Inc., and Fintech: Managerial Psychology, Corporate Governance and Business Processes. SSRN Working Paper, 2015, available online.

${ }^{83}$ See M. Grubisic, M. Nusinovic and G. Roje, Towards Efficient Public Sector Asset Management, Financial Theory and Practice 33(3), 2009, pp. 329-362, available online.
} 
FinTech-enabled public procurement promises to make procurement supply just as dynamically responsive to real-time market conditions as in private sector markets. Smart contracts can leave procurement terms flexible -- thus allowing for greater flexibility in price discovery (particularly around supply contracts) -- adjusting in real time to changing interest rates, exchange rates, prices, and other market terms, and using automatic funds transfers which select the cheapest method of transfer. ${ }^{84}$ After the contract award, FinTech-enabled project finance and lending could facilitate interest payments to vendors in real-time (adjusting frequently to complex swap and other terms), shifting repayment schedules, contingent payments, and so forth. Parties all along the supply chain could even extend to each other credit or ownership stakes (in immediately securitized and transferable digital tokens and others contracts). For vendor insurance (from contract performance insurance to insurance on materials used in providing a good, work or service), FinTech-enabled applications could help refine premium pricing, ensure timely premium payments, enable 'dynamic' pricing, and payment if triggering events occur. ${ }^{85}$ Dynamic ledgers could ensure the accurate recording of carbon credits, energy coupons, and other kinds of 'chits' aimed at introducing market-like mechanisms into traditionally non-market industries during procurements. ${ }^{86}$

For all its purported benefits, one of the dangers of FinTech-enabled procurement stems from simply replacing one form of credit card or currency with another - and calling it FinTech. The Angeleno Card represents an example - whereby local Los Angeles residents obtained government services through the use of a card given out by the government, rather than by banks. ${ }^{87}$ Or as Forbes points out, one bank (Cross River) actually provides the funds that seem to come from a whole diverse FinTech ecosystem. ${ }^{88}$

FinTech's newness potentially will lead to systemic problems and potential fraud as a very real possibility. Arslanian and Fischer wrote an entire book on the potential problems involved in transferring over to, and using, a new financial ecosystem. ${ }^{89}$ The early days of Wirecard show that fraud can occur by selling something as a miracle FinTech solution -- only to have the promoters skip town with investors' money. ${ }^{90} \mathrm{I}$

\footnotetext{
${ }^{84}$ For more, see John Ream, Yang Chu, David Schatsky, Upgrading Blockchains, Deloitte Insights, 2016, available online.

${ }^{85}$ Insurance in public procurement represents an even more obscure part of finance than procurement finance itself. Yet, awards of ineffectiveness (contract cancellations) can cost bidders millions - making such insurance more popular. See Duffie Osental, CLS Risk Solutions Launches Public Procurement Insurance in Light of Recent Court Ruling, Insurance Business Magazine, 2019, available online.

${ }^{86}$ For an even more optimistic vision, see Seong-Kyu Kim and Jun-Ho Huh, Blockchain of Carbon Trading for UN Sustainable Development Goals, Sustainability 12(10), 2020, available online.

${ }^{87}$ Emily Bary, Government is Partnering with Big Banks, Fintech to Speed Payments to Americans, MarketWatch, 2020, available online.

${ }^{88}$ Antoine Gara, Nathan Vardi and Jeff Kauflin, The Forbes Investigation: Inside the Secret Bank Behind The Fintech Boom, Forbes, 2019, available online.

${ }^{89}$ See Henri Arslanian, Fabrice Fischer, The Future of Finance: The Impact of FinTech, AI, and Crypto on Financial Services, Palgrave, 2019.

${ }^{90}$ For more on the fraud, see Lionel Laurent, Wirecard Scandal Could Give Fintech a Bad Name, Bloomberg, 2020, available online. Authors like Zeranski and Sancak might argue that under-regulation -rather than anything inherent in FinTech itself -- represents the cause of such fraud and potential corruption. See Stefan Zeranski and Ibrahim Sancak, Does the 'Wirecard AG' Case Address FinTech Crises?, SSRN Working Paper 3666939, 2020, available online.
} 
promised earlier not to talk about security or technical standards. Yet, without a common standard and demonstrated reliable regulation, government assets may be too vulnerable to 'digitize' (at least the securitized and digital form of ownership rights to them). ${ }^{91}$

Another of FinTech's dangers lies in its ability to help governments further push public responsibilities off its balance sheets. Co-finance, crowd-finance, and the public holding of rights or assets in digital/crypto form -- if the past serves as any indication -will just encourage governments to further renege on budgetary obligations. ${ }^{92}$ At the extreme, such actions aid in privatizing the state. ${ }^{93}$ Or at the opposite extreme, by giving contracting authorities significant power over both bidders and the very capitalist system they operate in. ${ }^{94}$ In theory, procurement policy should be indifferent to a country's internal public-private sector organization. Yet, most of the discussion around FinTech in the public sector leans toward figuring out how to make citizens pay for public goods directly, rather than help governments and public entities provide them. ${ }^{95}$

\section{Why Should We Care About Procurement Principles?}

As government officials look to FinTech to modernize public procurement, they need to keep general procurement principles in mind. Throughout the procurement process, tendering rules will affect the terms of project finance - in effect tying the adoption of FinTech in public procurement to procurement law itself. Firms' demonstrating financial capacity represents an obvious example. ${ }^{96}$ Financing costs in public service contracts represent another example where bidders may have latitude to make projects look cheaper ex-ante than they are ex-post.$^{97}$ Procuring micro-finance services, the treasury services of a private bank, and/or using investment intermediaries to deal with public debt represent less certain examples of FinTech in the public space. ${ }^{98}$ The flexibility given to contracting authorities to change tenders according to bidders' information and ideas (in

\footnotetext{
91 Timothy Massad, It's Time to Strengthen the Regulation of Crypto-Assets, Brookings Working Paper, 2019, available online.

92 Or at least reduce expenditures on those areas in the future. See Anis Chowdhury and Jomo Kwame Sundaram,World Bank's 'Mobilizing Finance for Development' Not Financing Development, IPS, 2020, available online.

93 Julian Gruin, Financializing Authoritarian Capitalism: Chinese Fintech and the Institutional Foundations of Algorithmic Governance, Finance and Society 5(2), pp. 84-104, 2019, available online.

${ }^{94}$ As previously noted, Hughes sees FinTech as liberating firms and citizens. For Fouillet and MorvantRoux, FinTech represents a way states can further control their populations. See Hughes, supra at 10. See also Cyril Fouillet and Solène Morvant-Roux, Financial inclusion, a driver of state building in India and Mexico? International Development Policy Review 10(1), 2018, available online.

${ }^{95}$ For examples, see Hemen Mark Butu, Benyoh Nsafon Sang-Wook Park and Jeung-Soo Huh, Leveraging Community Based Organizations and Fintech to Improve Small-Scale Renewable Energy Financing in Sub-Saharan Africa, Energy Research \& Social Science 73, 2021, available online.

${ }^{96}$ PSD at art. 19.2, para. 2, art. 58.1(b). FinTech poses some difficulty for art. 58.3, requiring bidders to show their assets and liabilities. If FinTech helps move money quickly, bidders can temporarily transfer large sums to meet bidding requirements. In theory, such fungibility poses no problem -- as art. 63.1 allows bidders to rely on the financial standing of other parties. I do not discuss this issue for reasons of space.

${ }^{97}$ PSD, at art. 13(b).

${ }^{98}$ In theory, the Directives exclude financial services from the procurement rules. However, FinTech does not fall directly into the Common Procurement Vocabulary (CPV) codes covering banking. See PSD, at art. 7(b) and 10(e).
} 
certain cases) require flexibility in the way bidders fund those ideas. Thus, existing public procurement principles will affect the introduction and use of FinTech in such procurement. Several themes and trade-offs stand out, especially in the EU's case law.

Rules versus discretion. FinTech's rule-based nature can come into conflict with current jurisprudence which allows for some purchasers' discretion. The Directives make ample room for negotiation between contracting authorities and bidders (offering at least 3 procedures making explicit reference to changes in procurement documents). ${ }^{99}$ EU case law, furthermore, has upheld contracting agency discretion (within limits) time after time. Examples include SIAC most importantly; and NATS Services v. Gatwick in the UK, which established some judicial deference toward contracting authorities and tender juries. ${ }^{100}$ Such rulings suggest that public buyers have a relatively large leeway in adopting FinTech technologies.

The struggle between rules and discretion has produced two doctrines in particular which FinTech applications would have a hard time emulating. First, contracting agencies must code rules -- and bidders must code responses -- which interpret bidding requirements relative to a "reasonably well informed and diligent tenderer." 101 Artificial intelligence applications - by extrapolating rules from the successes and failures of other bidders and past bids -- might eventually arrive at such behaviour. But contracting agencies and courts would have some difficulty deciding just how much algorithmic training the FinTech application needs before approximating such a standard. ${ }^{102}$ Second, no algorithm could likely decide whether a bidder has a solidarity objective (versus capitalization objective) which exempts a body from liability under state aid rules. ${ }^{103}$ One could imagine, though, FinTech technologies encouraging courts to agree with more specific rules provided for in computer code.

Disclosure versus effective remedy. Transparency represents a core value in most national procurement law. ${ }^{104}$ Many of FinTech's advocates crow about the extra transparency blockchains and related FinTech technologies will bring to tenders. Yet, some aspects of FinTech -- particularly neural network and algorithmic-based learning and closed development standards -- serve as proverbial black boxes. In theory, agencies need not disclose all scores given to bidders -- as several cases have affirmed contracting authorities' right to conceal sub-criteria. ${ }^{105}$ Smart contracts could (rightly or wrongly)

\footnotetext{
99 These include the competitive procedure with negotiation (art. 29.5), competitive dialogue (art. 30.6 para 2) and the innovation partnership (art. 31.4). See PSD at articles cited.

${ }^{100}$ See SIAC Construction Ltd v County Council of the County of Mayo (ECLI:EU:C:2001:553), hereinafter "SIAC", available online. See also NATS Services v. Gatwick, [2014], EWHC 3728, available online.

${ }^{101}$ See SIAC. See also Healthcare at Home.

102 Such 'reasonable person' standards extend across the law. For a discussion of the issues and a parallel 'reasonable robot' test, see Ryan Abbott, The Reasonable Robot: Artificial Intelligence and the Law, Cambridge, 2020 (especially at Chap. 3).

${ }^{103}$ See Fenin. See also EasyPay v. Finance Engineering C-185/14, EU:C:2015:716.

${ }^{104}$ In the EU for example, transparency represents a core value. See Kirsi-Maria Halonen, Roberto Caranta, and Albert Sanchez-Graells (Eds.), Transparency in EU Procurements: Disclosure Within Public Procurement and During Contract Execution, Edward Elgar, 2019.

${ }^{105}$ E.g. AbbieVie v. NHS and ATI. See ATI, C-331/04, ECLI:EU:C:2005:718.
} 
contain undisclosed rules by or for both buyer and seller. For example, one could easily imagine financing contract covenants contingent on the borrower's performance of some activities - like buying insurance or maintaining a certain credit score.

Such a lack of such disclosure though can conflict with the EU remedies regime. Bidders can not contest infringements they know nothing about. Most procurement regimes require adequate remedies for slighted bidders. ${ }^{106}$ Yet, the automated nature of some aspects of the FinTech-enabled procurements described above do not allow for breaches of contract (especially when the 'code is the contract'). ${ }^{107}$ As such, FinTech applications can deny to economic operators the information or opportunity to file complaints. Bidders can not prove breaches of rules designed to increase transparency without such transparency in the first place. Even proving basic errors -- like "manifest breaches" (of tender scoring rules for example) -- could prove impossible. Worse, FinTech applications themselves may provide inferences needed to deduce undisclosed, confidential or secret information. With access to enough information about bidders' and their bids, economic operators can basically "game" the system. Contracting authorities will thus need to resolve these dilemmas in their FinTech applications' code.

FinTech as public utility versus restricting competition in financial markets. EU procurement law stresses the immateriality of the internal organization of a country's economic structure. ${ }^{108}$ Governments should finance public activities via the budget, or a public FinTech (bank), or regulated private FinTech solutions, as desired. If governments pay for certain goods and services, numerous cases encourage contracting authorities to seek the widest amount of participation by eligible bidders in public tenders. ${ }^{109}$ These authorities may thus seek to participate in FinTech schemes lower all these bidders' cost of capital on an equal/proportionate basis. Some even see FinTech as a public utility -particularly given its network economics - like public transport networks. ${ }^{110}$

If the government supports FinTech-enabled public procurement applications, credits and financing from these applications might favour some firms over others. Such support could thus violate the non-discrimination and equal treatment principles enshrined in procurement law. ${ }^{111}$ Indeed, early analysis suggests that FinTechs could displace

\footnotetext{
${ }^{106}$ E.g., Sope Williams-Elegbe, Public Procurement, Corruption and Blockchain Technology in South Africa: A Preliminary Legal Inquiry, In Geo Quinot and Sope Williams-Elegbe (Eds), Regulating Public Procurement in Africa for Development in Uncertain Times, Lexis Nexis, 2020, available online.

${ }^{107}$ For this dilemma, see Larry Dimatteo, Cristina Poncibo, Quandary of Smart Contracts and Remedies: The Role of Contract Law and Self-Help Remedies, European Review of Private Law 26(6), 2018, available online.

${ }^{108}$ PSD, at art. 1.6.

109 See especially Domenico Politano Case C-225/15 ECLI:EU:C:2016:645. See also Partner Apelski Dariusz C-324/14 ECLI:EU:C:2016:214.

${ }^{110}$ E.g., see Neil Ainger, Banking to Become Open and a Utility says FinTech Chief, CNBC, 2017, available online.

${ }^{111}$ In a free market context, some FinTech providers have already proven discriminatory. See Robert Bartlett, Adair Morse, Richard Stanton \& Nancy Wallace, Consumer-Lending Discrimination in the FinTech Era, NBER Working Paper 25943, 2019, available online.
} 
traditional financial firms - definitely not a market neutral outcome. ${ }^{112}$ Even indirect support or block support to all firms could be discriminatory (at best) and/or distortionary (at worst). Imagine a bidder who ticks certain tender sub-criteria just to get access to cheaper credit. The government buyer's mere bid design, which affects the cost of a bidder's capital, could give responding firms an unfair commercial advantage. Such an advantage could easily fall afoul of state aid or competition law.

The principles regarding financial regulation do not necessarily overlap with those of public procurement. Both laws cherish a level playing field between undertakings of any kind -- in bids as well as in market conduct. ${ }^{113}$ Most governments keep any 'brainstorming' about procurement firmly within their financial supervisory bodies. ${ }^{114}$ The current thinking on FinTech regulation involves trial-and error (in sandboxes) or best practice, overseen by financial authorities. ${ }^{115}$ Such financial regulators focus on financial systemic stability, innovation, costs and access -- among other principles. ${ }^{116}$ Yet, procurement's focus on the public interest and solidarity have given procurement bodies - even those in central banks - license to procure FinTech services subject to both sets of law. ${ }^{117}$ Central bank procurement clearly falls under procurement law. These deliberations about FinTech should involve procurement policy officials.

FinTech as Administrative Means Versus Policy End. The literature tends to treat FinTech in two ways. First, FinTech provides a means for procuring better goods, services and works more cheaply. Such a view argues that FinTech -- like e-procurement rules - simply serves to better achieve already existing policies and principles. Second, FinTech represents part of a broader, national innovation policy. Clearly, a large number of governments treat the development FinTech as an objective in itself. Indeed, many governments have tried to procure FinTech as an innovation (as discussed in the next chapter).

The view one takes determines the way officials regulate FinTech, and organize its regulators. Viewing FinTech like the next step of e-procurement puts FinTech policy in the hands of procurement policy and officials. Financial regulators regulate the use of FinTech applications and governmental agencies follow those rules like they might follow environmental or other standards. Viewing FinTech like innovation policy gives

\footnotetext{
${ }^{112}$ See Rene Stulz, FinTech, BigTech, and the Future of Banks, Journal of Applied Corporate Finance 31(4), 86-97, 2019, available online.

${ }^{113}$ Competition law applies just as much to the economic operator in the performance of a public contract as it does to a financial body in the open market.

${ }^{114}$ For one example, see Charles Taylor, Christopher Wilson, Eija Holttinen, and Anastasia Morozova, Institutional Arrangements for FinTech Regulation and Supervision, IMF Fintech Note No. 19/02, 2019, available online.

${ }^{115}$ In particular, see Marlene Amstad, Regulating FinTech: Objectives, Principles, and Practices, Asian Development Bank Institute Working Paper 1016, 2019, available online.

${ }^{116} I d$.

${ }^{117}$ The next section discusses the numerous central bank tenders with EU and international donor support. See Jorge García-Andrade and Phoebus Athanassio, National Central Banks and Community Public Sector Procurement Legislation: A Critical Overview, European Central Bank Legal Working Paper 3, 2006, available online.
} 
procurement officials a voice in the implementation of that policy. Such a view also provides centralized purchasing bodies, ancillary purchasing activities, and procurement services providers an important role to play in shaping the way procurement-related finance ${ }^{118}$ As long as they stick to linking tender documents to the subject matter of the procurement, contracting authorities can help push FinTech in any way decided by the sitting government.

Public procurement principles matter just as much to FinTech's evolution as financial regulations. Nothing requires financial regulators - at the national or international level to develop FinTech-enabled procurement services in a transparent way, favouring equal treatment (except as required by competition law), proportionality in regulation, and serving the public interest. The next section looks at some of those principles more specifically -- showing how the race to develop national FinTech ecosystems can lead to worse procurement outcomes -- at home and internationally.

\section{The Principles Involved in Procuring a FinTech System}

\section{The Costs and Benefits of Procuring a FinTech Ecosystem/Standards}

Many authors argue for direct government involvement in 'procuring' FinTech (or a national FinTech ecosystem). In their view, private sector financial services firms will under-invest in innovative procurement-related FinTech services -- leading to significant under-investment at the national level. ${ }^{119}$ Regulatory sandboxes (and especially procurement sandboxes) represent one of the key ways governments encourage the private sector to develop such FinTech services. ${ }^{120}$ As these sandboxes expand, FinTech services -- and the needed regulation - expand at the same time. ${ }^{121}$ The poorly analysed initial data seem to already show that regulatory sandboxes lead to more FinTech growth. ${ }^{122}$ Such work encourages many governments to use procurement as a pro-active instrument in developing the very FinTech which would help make such procurements easier in the future. ${ }^{123}$

Governments thus actively ‘procure FinTech' -- awarding contracts to existing FinTech companies and organizations in the hopes of tripping on new technologies. For example,

\footnotetext{
118 See PSD, at art. 2.1(14)-2.1(17).

${ }^{119}$ For one statement, see Hsiao-Hui Lee, S. Alex Yang, and Kijin Kim, The Role of Fintech in Mitigating Information Friction in Supply Chain Finance, Asian Development Bank Economics Working Paper No. 599, 2019, available online.

${ }^{120}$ Sanchez-Graells paints one of the most well-rounded pictures of such an experiment. See Albert Sanchez-Graells, Procurement Sandboxes, Mock Procurements and Some Other Thoughts on Trying to Create Space for 'Real World' Experimentation, How to Crack A Nut Blog, 2017, available online. ${ }^{121}$ At least in theory. See Jon Truby, Fintech and the City: Sandbox 2.0 Policy and Regulatory Reform Rroposals, International Review of Law, Computers \& Technology, 2018, p.24. available online.

${ }^{122}$ See Jayoung Goo and Joo-Yeun Heo, The Impact of the Regulatory Sandbox on the Fintech Industry, with a Discussion on the Relation betweenRegulatory Sandboxes and Open Innovation, Journal of Open Innovation: Technology, Market and Complexity 6(43), 2020, available online.

${ }^{123}$ See Soumitra Dutta, Kanini Mutooni, and Arun Sharma, Accelerating the Emergence and Development of Innovation Ecosystems through Procurement: A Toolkit, World Economic Forum White Paper, 2019, available online.
} 
the Bank of Lithuania launched in 2018 a tender to develop LB Chain (LB for Lietuvos Bankas or Bank of Lithuania in Lithuanian). Selecting three firms -- Deloitte in Ireland, IBM in Poland and Tieto in Lithuania -- the Bank of Lithuania required these firms to consult with local FinTech firms to develop and test a "blockchain based product" to the Bank's specifications. ${ }^{124}$ At that project's wrap up meeting, Bank staff foresaw the blockchain 'project' evolving into a LTChain, which would serve non-financial firms.

Other initiatives -- funded by international organizations -- also show how authorities are trying to procure FinTech. The pilot blockchain project in Colombia represents one of the most apposite examples. ${ }^{125}$ The project aims to use the blockchain Ethereum with school meal providers in Medellin (Colombia) schools. ${ }^{126}$ The project received support from the Inter-American Development Bank -- among other organizations. Less directly focused on public procurement, the European Bank for Reconstruction and Development (EBRD) has funded a Bank of Greece project to develop FinTech products as part of a regulatory sandbox. ${ }^{127}$ The EBRD project represents one of the few FinTech projects sponsored by international organizations that actually went out to tender. ${ }^{128}$

Projects like these illustrate the problems involved in governments actively trying to influence the development of FinTech -- whether for use in public procurements or not. In the case of Lithuania's LB Chain, the project ended up moving away from blockchains and toward giving privileged access to information to privileged entities. ${ }^{129}$ The LB Chain received 'pre-commercial' support from the European Structural and Investment Funds and European Assistance for Innovation Procurement. ${ }^{130}$ Such pre-commercial support represents a kind of 'procurement for procurement' -- whereby the contracting agency finds out what to procure by procuring $R \& D$ which develops future procurements. $^{131}$

\footnotetext{
${ }^{124}$ European Commission, The Bank of Lithuania Starts Adding Fintech Companies' Innovations on the Blockchain, 2019, available online.

${ }^{125}$ Ian Hall, Colombian Blockchain Trial Cause For 'Cautious Optimism', says WEF, Global Government FinTech, 2020, available online.

${ }^{126}$ Ashley Lannquist and Rachel Raycraft, Exploring Blockchain Technology for Government Transparency: Blockchain-Based Public Procurement to Reduce Corruption, World Economic Forum Working Paper, 2020, available online.

${ }^{127}$ EBRD, Greece: Establishing a Regulatory Sandbox to facilitate FinTech and Innovation, 2020.

${ }^{128}$ Most of the international organizations have extensive cooperation with third parties in researching or conducting pilot FinTech projects. The IADB alone claims to have invested millions in activities like a Financial Innovation Lab, FinTechLAC and other initiatives.

${ }^{129} \mathrm{Or}$ as noted in an article on the project, "in response to feedback from the financial services sector, the bank had focused R\&D on permissioned systems rather than on public blockchains, choosing therefore to base LBChain on R3's Corda and Hyperledger Fabric." See Marie Huillet, Bank of Lithuania Envisions Future Cross-Industry Blockchain Platform, Coin Telegraph, 2020, available online.

${ }^{130}$ Pre-commercial support refers to a type of EU procurement whereby the contracting authority procures R\&D services from competing bidders. See European Commission, Pre-Commercial Procurement, 2020, available online.

${ }^{131}$ Such pre-commercial support usually represents the first stage of a longer term, multi-stage procurement. However, the terms of the entire procurement (going into 3 or more stages such as in the case of the EU's support of FinTech) may remain ill-defined or completely undefined. Needless to say, such support has been heavily criticized. See Charles Edquist and Jon Mikel Zabala-Iturriagagoitia, Pre-Commercial
} 
The international organizations' work on FinTech risks distorting FinTech development. Almost every international organization has some kind of FinTech unit or department. They manage hundreds of projects and person-hours every year in FinTech-related work. Some -- like the IADB -- even fund FinTech start-ups. Much of this work does not go out to tender. The self-managed nature of such a vast research programme across the international organizations takes hundreds of millions of dollars out of a potentially open international tender market. Few of these resources are directed under competitive bidding. ${ }^{132}$ Moreover, such work, done in collaboration with third-party organizations with connections to these organizations tacitly encourages the development of these burgeoning FinTech application providers over others -- especially those that might develop later. ${ }^{133}$ Foregoing future (and potentially better) FinTech solutions may represent one of the largest costs of the current push to procure FinTech. ${ }^{134}$

National governments' reliance on certain procurement procedures, which basically allow them to hand-pick partners, risks distorting FinTech's development. Procurement officials have long dealt with market research and innovation-based contracts. ${ }^{135}$ Such procedures lack much of the competitive nature that helps ensure value-for-money and best results. Yet, in cases where contracting organizations used some form of competitive bidding, project results have been lacklustre. ${ }^{136}$ As with other types of public financial support for innovation, procuring FinTech innovation so early in the technology's development risks locking it into an inefficient development path. ${ }^{137}$

\section{Principles in Procuring a National FinTech-Based Procurement Financing System}

\footnotetext{
Procurement: A Demand or Supply Policy Instrument in Relation to Innovation? R\&D Management 45(2), 2015, available online.

132 To the World Bank's credit, it does sometimes request information publicly in something that can look like a market research exercise. See World Bank, Distributed Ledger Technology or Blockchain Services, Solicitation Number: RFI 18-0075, 2017, available online.

${ }^{133}$ Favouring existing FinTechs, at the expense of FinTechs not yet developed, encourages lock-in toward existing technologies and 'violates' the rights of bidders who do not yet exist. Such 'future-proofing' as KPMG calls it, favours a status quo which, even the authors, want to move away from. See Heiko von der Gracht, Larry Giunipero, Marcus Schueller, Future-proof procurement, Now or Never: The Big Procurement Transformation, KPMG Working Paper, 2016, available online.

${ }^{134}$ Many procurement officers have put off choosing supply chain FinTech applications -- waiting for something better to come along. See Brielle Jaekel, Is FinTech the Future of Supply Chain?, Supply \& Demand Chain Executive, 2020, available online.

${ }^{135}$ For examples, see Oana Pantilimon Voda and Carolien Jobse, Rules and Boundaries Surrounding Market Consultations in Innovation Procurement, European Procurement \& Public Private Partnership Law Review 11(3), 2016, pp. 179-193, available online.

${ }^{136}$ Promoters like Adamonis (the Bank of Lithuania's project manager for the project) have claimed that the project helped attract foreign investment and cooperation from academic institutions from around the EU. No specifics usually see the light of day from pronouncements like this. See Marie Huillet, Bank of Lithuania Envisions Future Cross-Industry Blockchain Platform, Coin Telegraph, 2020, available online.

${ }^{137}$ We can not know for sure, as we can not observe technological trajectories not taken. However, the empirical evidence suggests that procurement displaces national innovation. See Francesco Crespi and Dario Guarascio, The Demand-Pull Effect of Public Procurement on Innovation and Industrial Renewal, Industrial and Corporate Change 28(4), 2019, 793-815, available online.
} 
To what extent does the public procurement of FinTech products and companies adhere to generally accepted procurement principles? Similiarly, to what extent does the use of FinTech applications like smart contracts or cryptoassets during the public procurement process conform with broader procurement jurisprudence? EU procurement law, for example, requires procedures which ensure transparency and equal treatment, while "taking into account sustainability criteria for social services." "138 Given finance's role in determining bidders' competitiveness, governments must ensure that companies generally have access to the same advantages (or that a particular company using an advantageous FinTech financier is not unreasonably advantaged). ${ }^{139}$ If the history of the digitization of procurement serves as any example, cheaper capital and looser procurement regulations may help encourage competition. ${ }^{140}$ Yet, the evidence from public-private partnership financing in the UK seems to show that the cost of capital is determined after the firm wins - and that such costs vary. ${ }^{141}$ As long as winning firms have access to the FinTech solution -- and as long as such finance takes the relative participation of government and the private sector into account, then such FinTech can benefit the whole market -- fairly. ${ }^{142}$

Many obstacles lie on the road to the fair procurement of FinTech or using FinTech fairly in procurements. Incumbent firms frequently participating in tenders (and thus used to existing procurement policies) have a competitive advantage. ${ }^{143}$ The EU Parliament has even warned about the potential for government policy to violate equal treatment and non-discrimination in encouraging FinTech through procurement and programmes like sandboxes and incubators. ${ }^{144}$ As such, a government-led development of FinTech for public procurement could distort the market more than help it.

Some configurations of general ledgers (like blockchains), smart contracts and the tokenization of cryptoassets could violate the transparency principle as well. Blockchains are harder to 'mine' for data than other forms of data storage and managing public

\footnotetext{
${ }^{138}$ PSD, at art. 76.

${ }^{139}$ More accurately, contracting agencies treat similar bidders in similar sitations equally. Small and medium enterprise (SME) policy enters so prominently in the Directives because SMEs' higher cost of capital may make their offers less competitive. See Carmela Di Mauro, Alessandro Ancarani, and Tara Hartley, Unravelling SMEs' Participation and Success in Public Procurement, Journal of Public Procurement 20(4), 2020, available online.

${ }^{140}$ E.g., see Anna Kochanova, Zahid Hasnain, and Bradley Larson, Does E-Government Improve Government Capacity? Evidence from Tax Compliance Costs, Tax Revenue, and Public Procurement Competitiveness, The World Bank Economic Review 34(1), 101-120, 2020, available online.

${ }^{141}$ Frederic Blanc-Brude and Roger Strange, How Banks Price Loans to Public-Private Partnerships: Evidence from the European Markets, Journal of Applied Corporate Finance 19(4), 2007, available online.

${ }^{142}$ Some scholars, and legal systems, might oppose such support on philosophical grounds, rather than strictly on the costs versus benefits of providing such support. See Gudula Deipenbrock, FinTech Unbearably Lithe or Reasonably Agile? - A Critical Legal Approach from the German Perspective, European Business Law Review 31(1), 3-32, 2020, available online.

${ }^{143}$ E.g., Mihaly Fazekas and Stephane Saussier, Colloquium, In Gustavo Piga, Tunde Tatrai, Law and Economics of Public Procurement Reforms, Routledge, 2017.

${ }^{144}$ Please note the principles in the Parenti's appendices. See Radostina Parenti, Regulatory Sandboxes and Innovation Hubs for FinTech: Impact on Innovation, Financial Stability and Supervisory Convergence, Report to the European Parliament PE 652.752, 2020, available online.
} 
permissioning may pose serious problems in FinTech's early years. ${ }^{145}$ Particularly, public disclosures may leak confidential information or information which can/should remain public for only a limited period. ${ }^{146}$ Until blockchains can handle the automated provisioning of information, government purchasers will need to question how much and what -- information can be put on blockchains. ${ }^{147}$

To what extent can procurement agencies or contracting agencies require the use of a FinTech solution in their invitations to bid (and thus bidding documents and contracts)? When do such requirements become disproportional to their supposed aims? The EU mandated that contracting authorities adopt e-procurement toward the end of the 2010s -without legal challenge. ${ }^{148}$ If such requirements help cement the common market - and compete with China (as discussed at length later) - such mandates may improve procurement outcomes and 'the European project. ${ }^{\text {, }}{ }^{19}$ Evidence from Greece reaffirms the experience across the EU that government agencies of all kinds have had difficulty accepting and implementing e-procurement activities. ${ }^{150}$ Even if EU and other courts accept FinTech measures as proportional to their procurement aims, nothing guarantees buy-in from budgeting entity heads.

\section{Is FinTech Procurement a Service of General Public Interest... Or State Aid?}

Could governments regulate FinTech services as utilities? Procurement policy might encourage FinTech's development through, "special or exclusive rights granted by Member States concerning the supply to, provision or operation of networks for providing the services concerned" (i.e. FinTech)? ${ }^{151}$ For example, the World Bank has partly funded Ghanaian mobile operator AirtelTigo's mobile money application. ${ }^{152}$ The

\footnotetext{
${ }^{145}$ The difficulty in scraping blockchains for information posed significant problems for a World Bank survey of blockchains. See Joseph Huntington La Cascia, Blockchain Lessons for Procurement, Procurement iNet, 2021, available online.

${ }^{146}$ Raquel Carvalho, Blockchain and Public Procurement, European Journal of Comparative Law and Governance 6(2), 2019, available online.

${ }^{147}$ FinTech promoters point to the high security of distributed ledgers like blockchains. Yet, not all applications in a procurement setting, are as easy to secure as others. See August Thio-ac, Alfred Keanu Serut, Rayn Louise Torrejos, Keenan Dave Rivo, and Jessica Velasco, A Blockchain-Based System Evaluation: The Effectiveness of Blockchain on E-Procurements, Cryptography and Security arXiv 1911.05399, 2019, available online.

${ }^{148}$ Some member states even tried to exceed the Commission's requirements. See Luís Soares and Adao Carvalho, E-Procurement and Innovation in the Portuguese Municipalities: When Change Is Mandatory, State, Institutions and Democracy, In Norman Schofield and Gonzalo Caballero (Eds), State, Institutions and Democracy, 363-388, 2016, available online.

${ }^{149}$ Christopher Bovis, Financing Services of General Interest in the EU: How do Public Procurement and State Aids Interact to Demarcate between Market Forces and Protection? European Law Journal 11(1), pp. 79-109, 2005, available online.

${ }^{150}$ See Charalampos Platis, Ioannis Karafyllis and Georgia Kaoura, E-Procurement in Public Hospitals in Greece, In Androniki Kavoura, Efstathios Kefallonitis and Apostolos Giovanis (Eds.), Strategic Innovative Marketing and Tourism, 1169-1177, 2019, available online.

${ }^{151}$ E.g., Utilities Directive 2014/25 at Recital (1).

${ }^{152}$ The World Bank provides a partial subsidy for low-income residents of Accra. See John Ikeda and Ken Liffiton, Fintech for the Water Sector: Advancing Financial Inclusion for More Equitable Access to Water, World Bank Discussion Paper, 2019, at p. 12, available online, hereinafter "Ikeda and Liffiton."
} 
application allows users to save money in order to buy subsidized toilets. The procurement of sanitation services and other utilities which will charge for their services thus give FinTechs a temporary economic advantage which they can use to provide services of a potentially general economic (or social) interest.

The EU Public Procurement Directive explicitly gives member states the right to provide such services as they see fit. ${ }^{153}$ Could part of FinTech's support for public procurement (or visa-versa, the procurement of FinTech) represent a "service of general public interest"? ${ }^{154}$ At first glance, FinTech certainly seems to represent such a "general economic interest." 155 FinTech - both as a sector and particular FinTech products definitely benefit from the 'network effects' that scholars have come to know these services of general economic interest by. ${ }^{156}$ If projects like the aforementioned LT Chain succeed, government money might have helped displace, and potentially replace, parts of the Lithuanian economy.

To what extent does the development of FinTech -- particularly for public procurement -represent such 'services of general economic interest'? ${ }^{157}$ First, these FinTechs would need to "discharge public service obligations and those obligations have been clearly defined." $" 158$ A public procurement solution for a member state, or operating EU-wide, would seem to provide such a public service. The second condition though seems far harder to meet. Namely, "parameters on the basis of which the compensation is calculated have been established beforehand in an objective and transparent manner."159 FinTech's uncertain technologies seem to make such a quantification and calculation impossible. The third and fourth planks of the Altmark test seem particularly problematic to prove -- as an alternative to a FinTech-based financing solution for public procurement already exists under competitive market conditions. Proving these third and fourth conditions similarly require a reasonably good cost-benefit analysis in order for governments to financially support FinTech networks' development for use in public procurement.

\footnotetext{
${ }^{153}$ PSD, at art. 1.4.

${ }^{154}$ EU state aid law codifies these services in its 2012 Decision. See Commission Decision 2012/21/EU On the application of Article 106(2) of the Treaty on the Functioning of the European Union to State aid in the form of public service compensation granted to certain undertakings entrusted with the operation of services of general economic interest (notified under document $\mathrm{C}(2011)$, available online.

${ }^{155}$ Grith Skovgaard Olykke and Peter Mollgaard, What is a Service of General Economic Interest? European Journal of Law and Economics 41, 205-241, 2013, available online.

${ }^{156}$ For example, see Leigh Hancher and Pierre Larouche, The Coming of Age of EU Regulation of Network Industries and Services of General Economic Interest, Tilburg Law School Research Paper No. 014/2010, 2010, available online.

${ }^{157}$ For these conditions, and broader background, see Wolf Sauter, The Commission's New SGEI Package: The Rules for State Aid and the Compensation of Services of General Economic Interest, TILEC

Discussion Paper 2012-018, 2012, available online.

${ }^{158}$ Originally from the Altmark case, the EU courts have made the four part test from the case into hard law. See Altmark Trans GmbH and Regierungspräsidium Magdeburg v Nahverkehrsgesellschaft Altmark $\mathrm{GmbH}$, and Oberbundesanwalt beim Bundesverwaltungsgericht, ECLI:EU:C:2003:415, available online. ${ }^{159} \mathrm{Id}$.
} 
What if such support consisted of developing common standards, rather than funding the build-out of such networks themselves? EU and other jurisdictions' procurement law have actively encouraged the setting of common standards which allow for cost-reducing standardization in procurement processing and the operation of electronic networks. ${ }^{160}$ Such standards -- especially if developed outside government -- could help foster the kind of innovation which might get FinTech-related procurement applications going. ${ }^{161}$ Yet, nothing guarantees that procurement officials can choose the best standards ex ante. ${ }^{162} \mathrm{At}$ its worst, such support may fund particular FinTechs, which may distort markets and break state aid law in some jurisdictions.

In the EU in particular, national government support for FinTech applications in public procurement may bump-up against state aid rules. ${ }^{163}$ Simply organizing tenders or auctions for FinTech companies may not protect contracting authorities from national competition law, procurement law or state aid rules. The EU has already considered the matter -- proposing measures aimed at countering the harmful effects of such aid (especially to financial services firms). ${ }^{164}$ Yet, nothing in EU procurement law absolves government entities of breaking procurement laws (or state aid law) by trying to remedy their effects 'downstream' -- even if such policies may promote consumer welfare after the fact. ${ }^{165}$ These mitigating policies may absolve contracting authorities of liability under competition law, but not procurement law.

Simply transferring such aid from states to their taxpayers directly does not solve the legal problems mentioned above. As mentioned previously, FinTech apps may allow public service users to directly pay for these services -- rather than pay into a government treasury account for them. FinTech applications might allow would-be taxpayers to pay for services which would otherwise consist of illegal state aid. Such a 'privatization' may also encourage the development of anti-competitive FinTech services and the provision

\footnotetext{
${ }^{160}$ The Pan-European Public eProcurement On-Line (PEPPOL) initiative represents just one example. Such standards have taken on renewed importance in green (environmentally friendly) procurement - where the debate continues on the government's role in promoting standards. See Anne Rainville, Standards in Green Public Procurement - A Framework to Enhance Innovation, Journal of Cleaner Production 167, 10291037, 2017, available online.

${ }^{161}$ Mercedes Bleda and Julien Chicot, The Role of Public Procurement in the Formation of Markets for Innovation, Journal of Business Research 107, 186-196, 2020, available online.

${ }^{162}$ Indeed, the experience from several emerging markets shows the folly in interventionist standard setting. See James Guild, Fintech and the Future of Finance, Asian Journal of Public Affairs 10(1), 52-6, 2017, available online.

${ }^{163}$ For one expression of such a fear, see Christopher Bovis, Financing Services of General Interest, Public Procurement and State Aid: The Delineation between Market Forces and Protection, Columbia Journal of European Law 10, 419, 2004, available online.

${ }^{164}$ Recognizing the network effects (benefits) likely to exist in any FinTech service offering, the EU has spent some time thinking about the ways of offsetting the harms from unfair competition and the market distortions large-scale FinTech providers may cause. See Alberto Carmona, Augustin Lombardo, Rafael Pastor, Carlota Quiros, Juan-Pablo Garcia, David Munoz, Luis Martin, Competition issues in the Area of Financial Technology (FinTech), DG IPOL Report IP/A/ECON/2017-20 PE 619.027, 2019, available online.

$\frac{}{165}$ Authors like Hainz and Hakenes, though, argue for subsidized lending on the grounds of lower welfare losses than direct subsidization. See Christa Hainz and Hendrik Hakenes, The Politician and His Banker How to Efficiently Grant State Aid, Journal of Public Economics 96(1-2), 2012, 218-225, available online.
} 
of permanent 'direct awards' by sidestepping government and its rules altogether. In most jurisdictions, water represents a public utility whose purchases fall under some kind of procurement policy. Yet, FinTech might provide a way to fund "off-grid" utility provision - in effect privatizing these hitherto public utilities. ${ }^{166}$ FinTech applications can also help target remittances toward paying a specific household's water bills and tracking subsidies with blockchains to ensure that subsidized users obtain the intended benefits. ${ }^{167}$

Support for FinTech-enabled public procurement applications thus needs to adhere to a number of conditions. First, such support would thus need to ensure an open architecture which gives no entity - including currently existing FinTech undertakings -an illegal or dubious advantage. The EU's FinTech Action Plan focuses on ensuring "technology-neutral" and "innovation promoting" policy. ${ }^{168}$ Yet, by ignoring procurement policy - while simultaneously continuing to work with central banks and international organisations on pilot FinTecch programmes -- such a policy does not even pretend to aspire toward technological neutrality.

Second, procurement law itself provides for a wide margin of negotiation and exemptions from such law. ${ }^{169}$ FinTech technologies even allow for entity-specific regulation, conducted via smart contracts. While "entity based" regulation and block exemptions may sound good in theory - governments should ensure an open debate and the transparent allotment of any such advantages. ${ }^{170}$ If government provides subsidies or subsidized services, they can use blockchain technology itself to track the way market participants transfer such advantages across the economy. The same FinTech tools which can help governments distort markets can also help them keep track of these distortions.

\section{Putting FinTech into Procurement Law: Preventing a Free-For-All}

\section{Can Contracting Authorities Let a Thousand FinTech Flowers Bloom?}

Why not let individual contracting authorities decide how to incorporate FinTech into their public procurement plans? ${ }^{171}$ The case law (at least in the EU) tends to allow

\footnotetext{
${ }^{166}$ For several examples from developing nations, see Ikeda and Liffiton, supra at note 154. Fintech for the Water Sector: Advancing Financial Inclusion for More Equitable Access to Water, World Bank Discussion Paper, 2019, available online.

${ }^{167}$ Id., at pp. 13-14.

${ }^{168}$ Chance provides a deeper analysis. See Clifford Chance, EU Regulatory Developments, Law and Financial Markets Review 14(2), 2020, pp. 128-139, available online. See also EU Commission, FinTech Action plan: For a more competitive and innovative European financial sector, Communication from the Commission COM(109), 2018, available online.

${ }^{169}$ EU authorities need worry less about such remedies -- as governments gained wide amounts of support even before the COVID-19 measures came into effect. See Fabio Falconi and Lars Suhr, The Application of European Competition Law in the Financial Services Sector, Journal of European Competition Law \& Practice 9(9), 2018, 604-616, available online.

${ }^{170}$ See Fernando Restoy, Fintech Regulation: How to Achieve a Level Playing Field, Financial Stability Institute Occasional Paper No 17, 2021, available online.

${ }^{171}$ Some authors argue strongly against any kind of central or government-wide policy. See Elvira Uyarra and Kieron Flanagan, Understanding the Innovation Impacts of Public Procurement, European Planning Studies 18(1), 2010, available online.
} 
contracting authorities wide discretion -- as long as they define FinTech-related issues clearly in their invitations to tender (or tendering documents). These authorities could stipulate how FinTech-using bidders should arrange financing or payment terms within their consortia or with the contracting authority itself. During the award, contracts could further specify how these FinTech-using contracting parties deal with these financing terms. Such contracts could treat all the parties to a contract as a loosely organized entity -- with contractual relations between all parties handled with Fintech-related technologies. ${ }^{172}$

In theory, FinTech-related technologies allow tenders and awards to be organized as Decentralized Autonomous Organizations (DAOs). Such DAOs allow for automation of contractual relations between the wide range of bidding and procuring entities party to a tender. ${ }^{173}$ More importantly, for some kinds of blockchains, parties can vote on particular aspects of bids or contracts, or change them according to fixed rules. Such voting would make these virtual procurement organizations 'dynamically democratic.' 174 Such DAOs will undoubtedly disrupt information-handling services like those found in public procurement. ${ }^{175}$

In practice, such DAOs have a long way to go before contracting authorities can use them as advertised. DAOs, as represented by Slock.it and others, represent poor, incomplete, unenforceable contracts. ${ }^{176}$ The inevitable complexities of modern business make complete DAOs (those without any break-points for pre-programmed human intervention) impossible. ${ }^{177}$ Yet, limited forms may automate and simplify (from the human users' point of view) procurement.

\footnotetext{
${ }^{172}$ Some evidence from the electric bus sector would seem to endorse such an approach. See Xiang-yi Li, Sebastian Castellanos and Anne Maassen, Emerging Trends and Innovations for Electric Bus Adoption - A Comparative Case Study of Contracting and Financing of 22 Cities in the Americas, Asia-Pacific, and Europe, Research in Transportation Economics 69, 470-481, 2018, available online.

${ }^{173}$ Such DAOs can emerge and disappear as temporary organizational forms, based on self-executing smart contracts. See Galia Kondova and Renato Barba, Governance of Decentralized Autonomous Organizations, Journal of Modern Accounting and Auditing 15(8), pp. 406-411, 2019, available online.

${ }^{174}$ Hsieh and his co-authors do not use the term explicitly - though the implication from their words is obvious. See Ying-Ying Hsieh, Jean-Philippe Vergne, Philip Anderson, Karim Lakhani and Markus Reitzig, Bitcoin and the Rise of Decentralized Autonomous Organizations, Journal of Organization Design 7(14), 2018, available online.

${ }^{175}$ For a quantitative look, see Soichiro Takagi, Organizational Impact of Blockchain through Decentralized Autonomous Organizations, International Journal of Economic Policy Studies 12, 22-41, 2017, available online.

${ }^{176}$ Minn describes the contractual issues involved with DAOs. Nielsen describes the technological challenges DAOs face, and the way governments help resolve them will determine how important DAOs become to procurement. See Kyung Taeck Minn, Towards Enhanced Oversight of "Self-Governing" Decentralized Autonomous Organizations: Case Study of the DAO and Its Shortcomings, New York University Journal of Intellectual Property and Entertainment Law 9, 139, 2020, available online. See also Timothy Nielsen, Cryptocurrencies: A Proposal for Legitimizing Decentralized Autonomous Organizations, Utah Law Review, 1105, 2019, available online.

${ }^{177}$ Quinn DuPont, Experiments in Algorithmic Governance: A History and Ethnography of 'The DAO,' A Failed Decentralized Autonomous Organization, In Malcolm Campbell-Verduyn (Ed.), Bitcoin and Beyond: Cryptocurrencies, Blockchains and Global Governance, Routledge, 2017.
} 
The public-private partnership (PPP) looks particularly apt for FinTech. ${ }^{178}$ These longlived projects involve large numbers of partner organizations, whose information and payments literally straddle the public-private divide. ${ }^{179}$ Governments often take equity stakes in these partnerships (an area ripe for crypto-securitization). ${ }^{180}$ Such publicprivate project finance of particular types of public spending -- particularly infrastructure projects -- could result in better project performance. ${ }^{181}$ Naturally, not all projects will benefit from PPP structures, or FinTech. ${ }^{182}$ FinTech - in PPPs as in other modes of public procurement -- can easily serve to distract managers and accountants in cases where no case for FinTech financing exists. ${ }^{183}$

The lack of a link to the subject matter may dissuade some contracting authorities from aggressively developing and using FinTech applications. EU case law -- for example -allows for public buyers to pursue public policies -- like innovation and thus FinTech - to the extent they have a link to a contract's main purpose. ${ }^{184}$ For example, disproportionate requirements forcing bidders to use certain types of renewable energy in the past have run into legal problems on such grounds. ${ }^{185}$ Contracting authorities might have a hard time convincing bidders and judicial bodies that FinTech requirements in invitations to tender and contracts represent proportionate, non-discriminatory and transparent policies. Letting government buyers -- even those like state-owned enterprises -- go outside the standard government finance rules to select (or mandate) their own financing terms invites corruption and self-serving.

\footnotetext{
${ }^{178}$ Readers unfamiliar with the financing structures around these projects should see Joaquim Miranda and Luc Renneboog, Anatomy of public-private partnerships: their creation, financing and renegotiation, International Journal of Managing Projects in Business 9(1), 2016, available online.

179 The next section describes the geopolitical implications of these partnerships. For a description of the way Chinese officials have already started thinking about using them, see Nir Kshetri, China's Emergence as the Global Fintech Capital and Implications for Southeast Asia, Asia Policy 15(1), 61-81, 2020, available online.

${ }^{180}$ The use of crypto-assets in infrastructure or other PPPs remains highly speculative -- even in China (one of the global leaders in FinTech). For a discussion, see Po-shan Yu, Zuo-zhang Chen and Jin Sun, Innovative Financing: An Empirical Study on Public-Private Partnership Securitisation in China, Australian Economic Papers 57(3), 394-425, 2018, available online.

${ }^{181}$ At least, as of 2014. See Eduardo Engel, Ronald Fisher, and Alexander Galetovic, Finance and PublicPrivate Partnerships, Stanford Centre for International Development Working Paper No. 496, 2014, available online.

${ }^{182}$ Indeed, private finance from any source can sometimes encourage adverse incentives. See Stephen Glaister, Past Abuses and Future Uses of Private Finance and Public Private Partnerships in Transport, Public Money \& Management 19(3), 29-36, 1999, available online.

${ }^{183}$ IFRS Rule 9 in particular on trade finance comes to mind. The marking of expected credit losses could require extensive algorithms and even inaccessible (from the reporting entity's point of view) data. Authors have worried about this since McQuaid and Scherrer (if not before). See Ronald McQuaid and Walter Scherrer, Changing Reasons for Public-Private Partnerships (PPPs), Public Money \& Management 30(1), 2010, available online.

${ }^{184}$ The link to the subject matter test remains a core part of EU procurement law. The test comes up in the literature most under discussions of green tech procurement. See Marc Martens and Stanislas de Margerie, The Link to the Subject-Matter of the Contract in Green and Social Procurement, European Procurement \& Public Private Partnership Law Review 8(1), 8-18, 2013, available online.

${ }^{185}$ Mariana Mazzucato and Gregor Semieniuk, Financing Renewable Energy: Who is Financing What and Why It Matters, Technological Forecasting and Social Change 127, 2018, p. 8-22
} 
Many argue that regulatory permissiveness (allowing parties to use FinTech as they see fit) represents the way to develop harder, black letter law on the subject. As thousands of contracting authorities write FinTech-based requirements into their procurement documents, both bidders and courts will have a chance to incorporate best practices into black letter law. ${ }^{186}$ By letting a thousand flowers bloom - figuratively speaking -procurement law can adapt to the benefits (and costs) that FinTech will impose on procuring bodies.

More likely, unfettered contracting authority discretion to develop and use FinTech apps might lead to an inefficient free-for-all. The inconsistent application of rules meant to help certain parties - like SMEs -- may end up serving the political or other interests of contracting authorities. ${ }^{187}$ Scholars and government officials have sought (for decades) ways of decreasing harmful competition between contracting authorities through centralized and/or aggregated purchasing. ${ }^{188}$ Left to their own devices, contracting authorities might engage in bidding wars and other unsocial behaviour. ${ }^{189}$ Econometric studies also show that placing restrictions on procuring agents can lead to better coordinated procurement - and thus procurement outcomes. ${ }^{190}$ If contracting authorities' discretion and differences across countries have served them - or their taxpaying beneficiaries -- so well, then why have so many people to change the status quo over the years ${ }^{191}$

\section{From SupTech/RegTech toward a Centralized Procurement Law}

Could supervisory technologies (SupTech) and/or regulatory technologies (RegTech) overcome the myriad of dangers that decentralized FinTech-enabled public procurement could cause? In theory, if contracting authorities can develop different FinTech solutions, then they can use the same technologies to regulate and supervise FinTech's use. Namely, blockchains, smart contracts, distributed ledger technology, and tokenization can help

\footnotetext{
${ }^{186}$ For one such proposal, see Charles Mooney, Global Standards for Securities Holding Infrastructures: A Soft Law/ Fintech Model for Reform, Michigan Journal of International Law 40, 531, 2019, available online.

${ }^{187}$ See Jian-lin Chen, Challenges in Designing Public Procurement Linkages: A Case Study of SMES Preference in China's Government Procurement, UCLA Pacific Basin Law Journal 30, 149, 2013, available online.

${ }^{188}$ See Albert Sanchez Graells and Ignacio Herrera Anchustegui, Impact of Public Procurement Aggregation on Competition. Risks, rationale and Justification for the Rules in Directive 2014/24, University of Leicester School of Law Research Paper No. 14-35, 2014, available online.

${ }^{189}$ From promoting local communities to outright war over limited products like ventilators or vaccines, procurement officials often find themselves in beggar-thy-neighbour positions. See Sean Markey, Laura Ryser and Greg Halseth, Local Content and Mobile Labour: The Role of Senior Governments in Capturing Benefits for Local Communities, Journal of Rural and Community Development 15(4), 2020.

${ }^{190}$ Erica Bosio, Simeon Djankov, Edward Glaeser and Andrei Shleifer, Public Procurement in Law and Practice, NBER Working Paper 27188, 2020, available online.

${ }^{191}$ Popescu and her colleagues have looked for 'best practices' in procurement - a common theme in a large literature which seeks to improve the lousy performance of procuring officials. See Ada Popescu, Mihaela Onofrei, and Christopher Kelley, An Overview of European Good Practices in Public Procurement: An Overview of European Good Practices in Public Procurement, Eastern Journal of European Studies 7(1), 81-91, 2016, available online.
} 
regulate and police procurement across the whole of government. ${ }^{192}$ Take a road works procurement as an example. The public sector buyer can use FinTech applications related to the financing of materials, distributing payments to contractors, transferring ownership with cryptographic tokens digitally, and provide real-time access to some project information to the public. ${ }^{193}$

Contracting authorities could adopt SupTech or RegTech apps just as easily as adopting FinTech applications. Over $66 \%$ of new RegTech providers target public sector organizations -- suggesting some kind of demand from government bodies. ${ }^{194}$ If DAOs can create self-contained procurements (with all the rules, including those on supply finance), then they can also contain all the rules (i.e. regulation) necessary for automated supervision. ${ }^{195}$ Yet, no obvious case suggests that a Ministry of Health (for example) might need different procurement regulations or supervision than a Ministry of Education. ${ }^{196}$

Even if contracting authorities adopt both FinTech applications and Reg/SupTech applications, they will require some common services. If Hong Kong's experience with e-procurement serves as a guide, then any regulatory approach should focus on adequate financial support (for the incorporation of FinTech in procurement in a sensible way), the interoperability of standards with traditional communication systems, and adequate security. ${ }^{197}$ Top management's understanding and support for such FinTech and RegTech adoption will also prove important (as well understanding the winning bidders' financial and other interests in the contract/award). ${ }^{198}$ If anything, weaker authorities might likely resist - rather than wholeheartedly embrace - FinTech-centred reform. ${ }^{199}$

\footnotetext{
${ }^{192}$ Such a view has many cheerleaders. See Cheng-Yun Tsang, From Industry Sandbox to Supervisory Control Box: Rethinking the Role of Regulators in the Era of FinTech, University of Illinois Journal of Law, Technology and Policy 355, 2019, available online. For a full-steam-ahead view, see also Yesha Yadav and Chris Brummer, Fintech and the Innovation Trilemma, Georgetown Law Journal 107(235), 2019, available online.

${ }^{193}$ Such an ecosystem-based approach to looking at roads risks encompassing all the logistics tied to those roads. In theory, FinTech-creep could extend as far as regulation allows. See Lenny Koh, Alexandre Dolgui and Joseph Sarkis, Blockchain in Transport and Logistics - Paradigms and Transitions, International Journal of Production Research 58(7), 2054-2062, 2020,

${ }^{194}$ See Emmanuel Schizas, Grigory McKain, Bryan Zhang, Altantsetseg Ganbold, Pankajesh Kumar, Hatim Hussain, Kieran James Garvey, Eva Huang, Alexander Huang, Shaoxin Wang, and Nikos Yerole, The Global RegTech Industry Benchmark Report, 2019, at p. 33, available online.

${ }^{195}$ See Olivier Rikken, Marijn Janssen and Zenlin Kwee, Governance challenges of blockchain and decentralized autonomous organizations, Information Polity 24(4), pp. 397-417, 2019, available online.

${ }^{196}$ Defence represents an obviously exception. Defence procurement often falls a different law than general public servcices procurement (such as the EU's Defence Directive). See Directive 2009/81/EC of the European Parliament and of the Council of 13 July 2009 on the coordination of procedures for the award of certain works contracts, supply contracts and service contracts by contracting authorities or entities in the fields of defence and security, and amending Directives 2004/17/EC and 2004/18/EC, available online.

197 Angappa Gunasekaran and Eric Ngai, Adoption of E-Procurement in Hong Kong: An Empirical Research, International Journal of Production Economics 113(1), 2008, pp. 159-175, available online. ${ }^{198}$ Id., at p. 169.

${ }^{199}$ Again, using e-procurement as a guide. See M. Jae Moon, E-procurement Management in State Governments: Diffusion of E-Procurement Practices and its Determinants, Journal of Public Procurement 5(1), 2005, available online.
} 
The potential for corruption and self-serving during the FinTech transition makes some central authority important. Even regulatory and supervision applications developed with the best of intentions could lead to poor social or other outcomes. ${ }^{200}$ Many procuring bodies in more corrupt jurisdictions would likely find ways of avoiding certain parts of smart contract applications which supervise their work (or just avoid supervisory tech all together). ${ }^{201}$ Without relatively honest civil servants and/or bidder businessmen, no amount of FinTech (or FinTech regulation) can help improve procurement's efficiency or value. ${ }^{202}$ RegTech applications could ironically shield government entities and bidders from oversight -- giving them the de facto power to self regulate using black-box applications that deter outside oversight. ${ }^{203}$

Could a central authority have the competence to oversee how government bodies use FinTech? Doesn't FinTech regulation fall strictly to financial regulators? Indeed, if past experience serves as a guide - the forced adoption of FinTech rules, as well as any regulatory or supervisory rules overseeing them -- can lower the cost of capital. ${ }^{204}$ In the EU, cases like EasyPay and Finance Engineering show just how seemingly ancillary activities like procurement finance fall under procurement law's remit. ${ }^{205}$ Given the wider ranging impacts of FinTech, traditional financial regulators will definitely need to cede some of their competencies to other bodies -- public and private. ${ }^{206}$

The need for centralized regulation will depend on each country's legal and business traditions. Some countries - like those with common law traditions - will naturally find contracting, information sharing and even the specification of digital assets easier in a FinTech-enabled procurement regime. ${ }^{207}$

\footnotetext{
${ }^{200}$ As corruption and fraud can arise from seemingly sensible rules. See Jean Shaoul, A Critical Financial Analysis of the Private Finance Initiative: Selecting a Financing Method or Allocating Economic Wealth? Critical Perspectives on Accounting 16(4), 441-471, 2005, available online.

${ }^{201}$ See Achmad Nurmandi and Sunhyuk Kim, Making E-procurement Work in a Decentralized Procurement System: A Comparison of Three Indonesian Cities, International Journal of Public Sector Management 28(3), 2015, available online.

${ }^{202}$ Studies in Sweden, a jurisdiction known for its low levels of corruption, find that dishonest vendors represented a major reason for the derailing of e-procurement. See Siriluck Rotchanakitumnuai, The Governance Evidence of E-Government Procurement, Transforming Government: People, Process and Policy 7(3), 2013, available online.

${ }^{203}$ While most authors write about these issues in the private sector context, the same issues abound in the case of public procurement. See Nizan Geslevich Packin, Regtech, Compliance and Technology Judgment Rule, Chicago-Kent Law Review 93, 193, 2018, available online.

${ }^{204}$ Lai and co-authors use the interesting case of the forced adoption of the SEC's digital EDGAR system in mid 1990s. See Sandy Lai, Chen Lin and Xiao-rong Ma, Regtech Adoption and the Cost of Capital, SSRN Working Paper 3683046, 2020, available online.

${ }^{205}$ For a spirited discussion, see Albert Sanchez-Graells and Ignacio Anchustegui, Revisiting the Concept of Undertaking from a Public Procurement Law Perspective - A Discussion on EasyPay and Finance Engineering, SSRN Working Paper 2695742, 2015, available online.

${ }^{206}$ Yueh-Ping Yang and Cheng-Yun Tsang, RegTech and the New Era of Financial Regulators: Envisaging More Public-Private-Partnership Models of Financial Regulators, University of Pennsylvania Journal of Business Law 21, 354, 2019, available online.

${ }^{207}$ For authors like Brownsword, lawyers will play a large role in working out the legality of market practice. Clearly, the call for legal scholarship he makes applies more to a common law tradition than to one less defined by principles. See Roger Brownsword, Regulatory Fitness: Fintech, Funny Money, and Smart Contracts, European Business Organization Law Review 20, 5-27, 2019, available online.
} 
In theory, procurement law already gives contracting authorities and even procurement bodies the authority to adopt FinTech (and RegTech). Most procurement law at the international, regional, and local level already allows for e-procurement. ${ }^{208}$ Government authorities in the past may have had significant difficulties adopting the regulation and working practices needed for such e-procurement. ${ }^{209}$ The complexities of regulating FinTech look far more daunting than the simple e-procurement tasks put in place in the past. If contracting agencies can require bidders to submit documents electronically only, can they not also require bids on blockchains ? $^{210}$ Can they require disclosures on distributed ledgers which may involve proprietary standards or unknown security standards? Can they require the adoption of the tokenization which allows titles to assets, consignment chains and other forms of possession and ownership to pass online under cryptographic lock-and-key? ${ }^{211}$

Legislators might adopt FinTech-friendly provisions in their national legislation. ${ }^{212}$ First, such amendments may consist of a simple yes or no as to whether procuring bodies can use blockchains, distributed ledgers, smart contracts, and/or tokens. The wide-spread use of FinTech in the public sector represents a political decision, which voters should have a right to shape. ${ }^{213}$ Second, some jurisdictions may even include a "right to innovate"

\footnotetext{
${ }^{208}$ Most procurement laws promote e-procurement. See Caroline Nicholas, Policy Choices in the Implementation of Electronic Procurement: The Approach of the UNCITRAL Model Law on Procurement to Electronic Communications, Public Procurement Conference, Seoul, South Korea, 2010, available online.

${ }^{209}$ The EU's attempt to define a governance regime for e-procurement illustrates some of the problems. See Sangeeta Khorana, Kirsten Ferguson-Boucher and William Kerr, Governance Issues in the EU's eProcurement Framework, Journal of Common Market Studies 53(2), 292-310, 2015, available online. ${ }^{210} \mathrm{Li}$ and co-authors strongly root for such tendering methods, without providing any data on their efficiency or security. See Li Li, Jia-yong Liu, and Peng Jia, SecTEP: Enabling Secure Tender Evaluation with Sealed Prices and Quality Evaluation in Procurement Bidding Systems over Blockchain, Computers \& Security 103, 2021, available online.

${ }^{211}$ The early attempts seem plagued with problems. See Yi-feng Tian, Zheng Lu, Peter Adriaens, Edward Minchin, Alastair Caithness and Junghoon Woo, Finance Infrastructure Through Blockchain-Based Tokenization, Frontiers of Engineering Management 7, pp. 485-499, 2020, available online.

${ }^{212}$ Thanks to the UNCITRAL's excellent work, most countries now have one or more pieces of legislation defining the rights and obligations of parties in a public procurement. Yet, vestiges remain of old systems where specific sectors (like defence or telecoms) have their own regimes. For example, the Japanese Deming-inspired 'quality drive' in the 1980s resulted in the consultation processes that many would consider conducive to corruption. See Shigeki Kusunoki, Japan's Government Procurement Regimes for Public Works: A Comparative Introduction, Brooklyn Journal of International Law 32, 2007, available online.

${ }^{213}$ The lack of scholarly attention to citizens' desire to vote for the use of FinTech and other advanced technologies in the public sector remains surprising. The Swiss referendum on money and scant popular press attention to the Biden White House's likely views on FinTech represent the main writings so far. See Sam Meredith, Switzerland is set to vote on a radical 'sovereign money' plan, $C N B C$, 2018, available online. See also Jim Saksa, What Would a Biden White House Mean for Fintech? Roll Call, 2020, available online.
} 
principle into their procurement laws. ${ }^{214}$ Such provisions could help contracting agencies adopt FinTech solutions, without overly worrying about getting in trouble or sued. Third, such laws may force FinTech applications to include "break points." 215 Such break points 'let the law in' by stopping automated routines and smart contracts at points where humans may try to negotiate or seek remedies and redress for wrongs committed by these applications and their writers/operators. Fourth, provisions for -- or a separate law on digital platforms would also help secure the type of FinTech ecosystems previously described. ${ }^{216}$

Such law may include more specific provisions related to setting up FinTech-enabled public procurement. First, such legislation may define the rights and limits of "guided sandboxes." 217 Such sandboxes represent specific procurements where contracting authorities could use FinTech-related technologies on a limited basis within the confines of a specific tender. Second, these laws may regulate how public entities use their newfound banking powers -- to the extent financial law does not cover these entities. ${ }^{218}$ Third, to the extent centralized bodies do not have the authority to make regulation, legislation can create them and give them powers.

Authorities besides financial regulators should regulate parts of FinTech's development. Few doubt the role that financial regulators must play -- particularly for FinTech applications used exclusively in the private sector and/or as a substitute for traditional finance. ${ }^{219}$ Few experts have concrete proposals for exactly how such regulation should occur -- or even over what kinds of transactions and networks they would occur over. ${ }^{220}$ Even concrete proposals on offer -- like allowing the US

\footnotetext{
${ }^{214}$ Giving public bodies too much leeway to innovate would violate the principle of rule of law and make award challenges far more likely... and costly. Yet, giving them some extra leeway may uphold the broader values of the procurement system. See Peteris Zilgalvis, The Need for an Innovation Principle in Regulatory Impact Assessment: The Case of Finance and Innovation in Europe, Policy and Internet 6(4), pp. 377-392, 2014, available online. See also Elvira Uyarra and Kieron Flanagan, Understanding the Innovation Impacts of Public Procurement, European Planning Studies 18(1), 2010, available online. ${ }^{215}$ Usha Rodrigues, Law and the Blockchain, Iowa Law Review 104, 679, 2019, available onine.

216 Teresa Ballell, The Legal Autonomy of Electronic Platforms: A Prior Study to Assess the Need of a Law of Platforms in the EU, Italian Law Journal 3, 149, 2017, available online.

${ }^{217}$ Wolf-Georg Ringe and Christopher Ruof, Regulating Fintech in the EU: the Case for a Guided Sandbox, European Journal of Risk Regulation 11(3), 2020, available online. See also Chang-Hsien Tsai and KuanJung Peng, The FinTech Revolution and Financial Regulation: The Case of Online Supply-Chain Financing, Asian Journal of Legal Studies 4, 109, 2017, available online.

${ }^{218}$ To the extent FinTech removes intermediaries like banks, government entities themselves could potentially hold digital wallets, seek crowd-sourcing, or cryptographically securitize assets/debts. Most countries' financial laws treat government entities differently from regular private sector organizations.

${ }^{219}$ For example, Goldstein et al. set up a contest to solicit manuscripts about the subject. See Itay Goldstein, Wei Jiang, G Andrew Karolyi, To FinTech and Beyond, The Review of Financial Studies 32(5), 2019: 1647-1661. Available online.

${ }^{220}$ Philip Treleaven, Financial Regulation of Fintech, Journal of Financial Perspectives 3(3), 2015, available online. See also William Magnuson, Regulating Fintech, Vanderbilt Law Review 71, 1167 (2018), available online.
} 
Office of the Comptroller of the Currency (OCC) to regulate FinTechs -- remain highly controversial. ${ }^{221}$ Given such an uncertain regulatory environment, governments should open up regulatory competencies to other agencies which FinTech applications affect. Central procurement bodies, to the extent they make policy or have a voice in the way that procurement finance develops, should have a seat at that regulatory table.

A central procurement body or ancillary services provider could draft specific rules for the use of each FinTech technology. For example, outlining the procedures used for communication between government bodies and bidders in a competitive dialogue -- or the extent to which smart contracts may be defined into a negotiated procedure. ${ }^{222}$ Such a body could even serve to develop the FinTech and/or RegTech applications for use across government. ${ }^{223}$ Yet, any government-encouraged FinTech supporting services for public procurement would likely raise the same concerns as already existing digital marketplaces and solutions. ${ }^{224}$ The central body could even police policy -- such as contracting authorities which try disguising certain types of awards or winners. ${ }^{225}$ Most important, though, such a body could deliberate on when to not regulate -- given the Innovation Trilemma. ${ }^{226}$

Such a central body could focus on developing common FinTech and regulatory standards. Simple examples -- such as the common procurement vocabulary (CPV) -show the importance and difficulty of establishing standards. The Pan-European Public Procurement Online project has saved up to $\$ 50$ million by encouraging the use of common technical standards inside as well as outside the EU. ${ }^{227}$ The body could ensure standardization across government -- from inter-operable blockchains and smart contracts, to the automatic payment of purchase orders. ${ }^{228}$ Such an entity could also serve as a counterpart in international negotiations over FinTech-related standards in generalized

\footnotetext{
${ }^{221}$ Elizabeth Upton, Chartering Fintech: The OCC's Newest Nonbank Proposal, George Washington Law Review 86(1392), 2018, available online.

${ }^{222}$ Because of the simplicity and predictability of some public supply contracts, such regulations could even exist in the form of procure-to-pay code. Such code would govern purchases uniformly across government. See Lorenz Trautmann and Rainer Lasch, Smart Contracts in the Context of Procure-to-Pay, Smart and Sustainable Supply Chain and Logistics - Trends, Challenges, Methods and Best Practices, pp 3-23, 2020, available online.

${ }^{223}$ Many companies offer such services. For one advertisement, posing as academic research, see Simone di Castri, Matt Grasser and Arend Kulenkampff, The RegTech for Regulators Accelerator (R ${ }^{2}$ A) Process: Giving Financial Authorities Superpowers, 2018, SSRN Working Paper, available online.

${ }^{224}$ Government control of an entire sector puts many ill at ease. See Michal Gal and Nicolas Petit, Radical Restorative Remedies for Digital Markets, Berkeley Technology Law Journal 37(1), 2021, available online.

${ }^{225}$ E.g., see Jan Palguta and Filip Pertold, Manipulation of Procurement Contracts: Evidence from the Introduction of Discretionary Thresholds, American Economic Journal 9(2), 2017, available online.

${ }^{226}$ Yesha Yadav, Fintech and International Financial Regulation, Vanderbilt Law Research Paper No. 20 45, 2020, available online.

${ }^{227}$ Original source quotes in US dollars. See Anonymous author, The Future of Public Procurement?, FinExtra Blog, 2014, available online.

${ }^{228}$ While standardization across government would seem to facilitate procurement, the data do not point in that direction. See Andrea Patrucco, Tommaso Agasisti and Andreas Glas, Structuring Public Procurement in Local Governments: The Effect of Centralization, Standardization and Digitalization on Performance, Public Performance \& Management Review 43(5), 2020, available online.
} 
procurement policies world-wide. ${ }^{229}$ Such a body could also oversee the procurementrelated aspects of regulation adopting the UNCITRAL-related work on trade finance. ${ }^{230}$

Some or complete independence from government may serve as one way of ensuring that a FinTech-enabled public procurement regulator or think tank would avoid the dangers of giving anti-competitive state aid. ${ }^{231}$ Such a body could consist of a supervisory board consisting of politicians, civil servants, businesspersons, technical experts (in finance and technology) and NGO representatives. The extent of such independence remains an open question -- as even supposedly independent regulators like the US Securities and Exchange Commission -- have a decidedly pro-government, enforcement bent. $^{232}$

\section{Preventing a Free-For-All in International Procurement Standards}

\section{The Promise of FinTech in Revitalizing Government-to-Government Procurement}

If FinTech promises to facilitate public procurement domestically, the benefits for crossborder procurement seem even greater. FinTech innovations like public blockchains -and a way to mine them for data -- could finally shed light on this little understood sector. ${ }^{233}$ Many cite the EU's 2011 figure of about \$1 billion in international procurements covered by the WTO's Agreement on Government Procurement (GPA). ${ }^{234}$ Roughly $33 \%$ of international trade involves some kind of bank-intermediated trade

\footnotetext{
${ }^{229}$ Maria Anna Corvaglia, Public Procurement and Private Standards: Ensuring Sustainability Under the WTO Agreement on Government Procurement, Journal of International Economic Law 19(3), 607-627, 2016, available online.

${ }^{230}$ The United Nations Committee on International Trade Law in Vienna (UNCITRAL) has pioneered work on four areas of relevance. Unfortunately, Lack of space prevents any discussion of the four model laws. These are the UN Convention on Assignment of Receivables in International Trade (2001), the UNCITRAL Legislative Guide on Secured Transactions (2007) and its 2010 Guide on Security Rights in Intellectual Property, its 2013 Guide on the Implementation of a Security Rights Registry, and its ongoing work on a Model Law on Secured Transactions.

${ }^{231}$ I. Erturk, and J. Zammit-Lucia, Building Digital Finance in Europe: FinTech for Social Value. RadixCentre for Business, Politics and Society, 2020, at p. 27, available online.

${ }^{232}$ In the financial law literature, the question of regulator independence has made the rounds for decades. Despite many finding significant advantages in such an arrangement, politics and social convention often block such independence. See Lisa Bressman and Robert Thompson, The Future of Agency Independence, Vanderbilt Law Review 63, 599, 2010), available online.

${ }^{233}$ Even in 2021, international bodies like the World Trade Organization (WTO) have little idea about the size of trade finance markets -- even though international organizations helped rescue them in 2007-8 and during the COVID-19 crisis. Authors like Han and colleagues bemoan the lack of digitization in export/import in Korea - a situation which has prevented any solid analysis of the sector. See Marc Auboin, Trade Finance, Gaps and the COVID-19 Pandemic: A Review of Events and Policy Responses to Date, WTO Staff Working Paper No. ERSD-2021-5, 2021, available online. See also Ki-Moon Han, Sae Woon Park and Sunhae Lee, Anti-Fraud in International Supply Chain Finance: Focusing on Moneual Case, Journal of Korea Trade 24(1), 59-81, 2020, available online.

${ }^{234}$ See Bernard Hoekman, International Cooperation on Public Procurement Regulation, In The Internationalization of Government Procurement Regulation, Aris Georgopoulos, Bernard Hoekman, and Petros Mavroidis (Eds.), Oxford, 2017, at p.573. Anderson et al. cite this same statistic. See infra note 240.
} 
finance. ${ }^{235}$ Yet, by some rough-and-ready measures, the costs of arranging such finance (at least in the EU) come to about one-fourth the benefits. ${ }^{236}$ The significant costs of trade finance impede international trade. ${ }^{237}$

FinTech could significantly lower the costs of cross-border trade and government procurement. Most international trade involves sending costly documentary evidence proving that buyers have the money to pay for shipments, and sellers have the goods to ship. Recent estimates find that traders use letters of credit and other documentary collections in roughly $15 \%$ of global exports. ${ }^{238}$ The significant effect that export insurance plays in promoting trade clearly shows that traders have problems financing trade and insuring such finance. ${ }^{239}$ FinTech-enabled procurement solutions could easily share blockchain and distributed ledger information to international parties. ${ }^{240}$ The tokenization of assets could reduce information and transaction costs. ${ }^{241}$

New FinTech-related law could also revitalize international efforts to simplify the law covering such trade. Over $80 \%$ of responding firms noted constraints on trade finance due to regulations or policies which FinTech could address. ${ }^{242}$ Many countries -- given their failure to adopt some multilateral treaties that facilitate international trade and procurement -- often offer export credits instead. ${ }^{243}$ These credits serve as the international equivalent of state aid in the EU context - making cross-border procurement less fair and profitable.

Left to their own devices, many countries would rather slow down - rather than speed up -- the adoption of measures in treaties like the Government Procurement Agreement

\footnotetext{
${ }^{235}$ Lee and co-authors cite the IMF for this statistic. See IMF, Sustaining the Recovery: World Economic Outlook, IMF Publication, 2009. See also Hau Lee, Christopher Tang, Alex Yang and Yuxuan Zhang, Dynamic Trade Finance in the Presence ofInformation Frictions and FinTech, SSRN Working Paper 363256, 2020, available online.

${ }^{236}$ Robert Anderson, Philippe Pelletier, Kodjo Osei-Lah and Anna Caroline Muller, Assessing the Value of Future Accessions to the WTO Agreement on Government Procurement (GPA): Some New Data Sources, Provisional Estimates, and an Evaluative Framework for Individual WTO Members Considering Access, WTO Staff Working Paper ERSD-2011-15, 2011, available online.

${ }^{237}$ For a quantification, see Marc Auboin, International Regulation and [the] Treatment of Trade Finance: What Are the Issues? WTO Staff Working Paper, No. ERSD-2010-09, 2010, available online.

${ }^{238}$ Friederike Niepmann and Tim Schmidt-Eisenlohr, International Trade, Risk and the Role of Banks, Journal of International Economics 107, 111-126, 2017, available online.

${ }^{239}$ Marc Auboin and Martina Engemann, Testing the Trade Credit and Trade Link: Evidence from Data on Export Credit, WTO Staff Working Paper ERSD-2012-18, 2012, available online.

${ }^{240}$ Hsiao-Hui Lee, Alex Yang, and Kijin Kim, The Role of Fintech in Mitigating Information Friction in Supply Chain Finance, ADB Working Paper No. 599, 2019, available online.

${ }^{241} I d$.

${ }^{242}$ For example, expensive know-your-customer rules become less important in a trustless environment. See Marc Auboin and Alisa Di Caprio, Why Do Trade Finance Gaps Persist: Does It Matter for Trade and Development? WTO Staff Working Paper, No. ERSD-2017-01, 2017, at p.13, available online.

${ }^{243}$ If authors like Levit bemoaned these credits in 2004, they still represent an important part of the trade landscape in 2021. See Janet Levit, The Dynamics of International Trade Finance Regulation: The Arrangement on Officially Supported Export Credits, Harvard International Law Journal 45, 65, 2004, available online.
} 
(GPA). ${ }^{244}$ At the very least, technical norms which make financing international procurement easier could encourage the development of more hard law and, thus, more international procurement. ${ }^{245}$ The most optimistic vision of FinTech sees technical standards completely replacing the need for law -- in effect doing for trade finance what technology did for international telephony. ${ }^{246}$

\section{Could FinTech Breath New Life into International Procurement Law?}

The major international agreements encouraging cross-border public procurement take a mixed view of e-procurement. The GPA encourages e-procurement in principle - but talks mainly about interoperability and data security. ${ }^{247}$ In effect then, the GPA offers far less encouragement of cross-border procurement than the EU Directives. Yet, "the GPA has direct implications for investment policy and for domestic economic reforms, and is an important tool of e-commerce." 248 The UNCITRAL Model Law on Public Procurement (the basis for many international organizations' procurement regulations and for many countries) only mentions that advances in information technology represents a reason for updating the Model Law. ${ }^{249}$ Electronic reverse auctions represent the only other serious mention of information technologies in the Model Law. ${ }^{250}$ Nothing in the World Bank's confusing set of documents comprising its Procurement Framework seems to mention anything about electronic procurement. ${ }^{251}$ Even its high level advice to member countries seems silent on the subject. ${ }^{252}$ At least the EBRD has sought advice on changing the ways it procures, specifically looking to build FinTech into its broader way of doing business. ${ }^{253}$

\footnotetext{
${ }^{244}$ Christopher Yukins and Johannes Schnitzer, GPA Accession: Lessons Learned on the Strengths and Weaknesses of the WTO Government Procurement Agreement, Trade Law and Development 7, 89, 2015, available online.

${ }^{245}$ See Ivo Krizic, The International Regulation of Competition Policy and Government Procurement: Exploring the Boundaries of the Trade Regime, New Political Economy 26(2), 2021, available online.

${ }^{246}$ If a host of laws and standards governed the way telephone operators connected a call across borders in 1960s, voice over IP has made the need for these laws almost irrelevant by 2020. See Chris Brummer, Why Soft Law Dominates International Finance_-and not Trade, Journal of International Economic Law 13(3), 2010, pp. 623-643, 2010, available online.

${ }^{247}$ The GPA's preamble rather generally and ambiguously encourages the use of electronic means. Only one provision deals directly with "electronic means" - requiring interoperability with other "generally available" technology, and IT security. The phrase "electronic or paper media" appears throughout the text, highlighting the framers' intention to encourage e-procurement. See GPA at preamble point 8, and in particular art. 4.3, p. 5, 2012, available online.

${ }^{248}$ Robert Anderson and Anna Muller, The Revised WTO Agreement on Government Procurement (GPA)L Key Design Features and Signficance for Global Trade and Development, Georgetown Journal of International Law 48, 2017, available online.

${ }^{249}$ UNCITRAL Model Law on Public Procurement, 2014, at preamble point 6, available online.

${ }^{250} I d$. at Chap. VI.

${ }^{251}$ See World Bank, Procurement Framework and Regulations for Projects After July 1, 2016, available online.

${ }^{252}$ The Bank's Bali FinTech Declaration makes sweeping statements about how the Bank will 'deliver' the FinTech revolution to members. The lack of practical guidance documents related to procurement specifically makes such a delivery dubious. See World Bank, The Bali Fintech Agenda, World Bank Report Number 130563, available online. See also World Bank, Project Procurement Strategy for Development: Long Form Detailed Guidance, 2016, available online.

${ }^{253}$ See EBRD, Research study of Fintech solutions in selected EBRD COOs. 2017, available online.
} 
No procurement treaty can work without the liberalization of the financial services that make such FinTech-enabled public procurement possible. In this sense, progress on the General Agreement on Trade in Services (and especially financial services) must occur with progress on the GPA. ${ }^{254}$ Progress on financial sector liberalization under the Agreement (or GATS) and other agreements like Trade in Services Agreements and other regional agreements has proceeded falteringly. ${ }^{255}$ The use of prudential carve-outs and plain-old footdragging has continued to the point where any serious liberalization of cross-border FinTech services only looks likely to occur either in preferential trade areas or bilaterally. ${ }^{256}$ If countries lived up to their GPA commitments (much less their other commitments under regional and multilateral trade agreements) -- the trade in financial services would increase. ${ }^{257}$ Yet, in order to create an international FinTech-enabled procurement market, regulators must tackle rulemaking in the finance as well as procurement fields. $^{258}$

If FinTech affects international law, such effects will take place on a contract-by-contract basis. In theory, international agreements do not forbid (or even necessarily discourage) the use of technologies and electronic means. ${ }^{259}$ Yet, if cross-border parties to a public procurement wish to use FinTech apps, their contracting terms will likely need to specify such use. Such a case-by-case basis for FinTech's use gives rise to a potential FinTech free-for-all. As long as nothing prohibits FinTech's use in contracting, procuring entities and foreign suppliers can offer, require and use any FinTech applications they desire.

Such a free-for-all would discourage the development of a principles-based multi-lateral public procurement system in three ways. First, the lack of common standards for blockchains will slow down the accession of some of the lesser developed countries acceding to the GPA. Lesser developed countries often tend to just copy other countries' standards, and adopt the most popular standard. Lack of such popular standards would keep these countries in a state-of-waiting. Second, keeping FinTech-related standards in contracts -- while certainly in line with the philosophy of international donor organizations -- would do little to build minimum standards in international law. ${ }^{260}$ Both

\footnotetext{
${ }^{254}$ Anderson et al. see the two agreements -- and the two topics of finance and public procurement -- as inexorably linked. See Robert Anderson, Claudia Locatelli, Anna Caroline Muller, and Philippe Pelletier, The Relationship Between Services Trade and Government Procurement Commitments: Insights from Relevant WTO Agreements and Recent RTAs, WTO Working Paper ERSD-2014-21, 2014, available online.

${ }^{255}$ Rudolf Adlung, The Trade in Services Agreement (TISA) and Its Compatibility with GATS: An Assessment Based on Current Evidence, World Trade Review 14, 617, 2015, available online.

${ }^{256}$ Carlo Maria Cantore, The Prudential Carve-Out for Financial Services: Rationale and Practice in the GATS and Preferential Trade Agreements, Cambridge, 2018.

257 A. Ueno, Multilateralising Regionalism on Government Procurement, OECD Trade Policy Paper No. 151, 2013, at p. 2, available online.

${ }^{258}$ Lev Bromberg, Andrew Godwin and Ian Ramsay, Cross-Border Cooperation in Financial Regulation: Crossing the Fintech Bridge, Capital Markets Law Journal 13(1), pp. 59-84, 2018, available online.

${ }^{259}$ Emmanuelle Gann, Can Blockchain Revolutionize International Trade?, WTO Working Paper, 2018 , p. 68, available online.

${ }^{260}$ The World Bank and the EBRD (the two organizations that embody the two procurement philosophies used by international aid and finance organizations) both seek to rely on borrower's own procurement
} 
the GPA and GATS favour the kind of multilateralism - through the use of most favoured nation (MFN) rules -- that would encourage the adoption of the least restrictive rules when using FinTech in government procurement. ${ }^{261}$ A contract-by-contract approach to adopting FinTech in public procurement would thus deprive some countries from benefiting from potentially advantageous FinTech-related terms that others have adopted. Third, if donors like the World Bank decide to pursue FinTech aggressively, they risk reintroducing 'minimum standards' into procurement which they have tried to swear off for years. The vacillation between using recipient country rules and a donor's rules has made international procurement more complex - and sometimes even led to complete project failure. ${ }^{262}$ The European Development Fund's rules on recipient countries' procurements have - in some cases - hampered (rather than encouraged) the development of local procurement systems. ${ }^{263}$

Such a free-for-all would have FinTech-enabled public procurement legal standards developing in a relative vacuum. FinTechs -- because they operate online and thus easily across national borders -- should need to, at least, announce which regulator they fall under. ${ }^{264}$ Even such a minimum standard would have its opponents (in that the FinTechs themselves prefer the lightest regulatory touch possible). Similarly, establishing national jurisdiction may prove impossible for crypto-assets transferred electronically according to rules in one jurisdiction which apply to goods in another jurisdiction. ${ }^{265}$ At a bare minimum, regulators should adopt law which ensures the adherence to principles like the rule of law, transparency, and proportionality. ${ }^{266}$

\section{Chinese FinTech and Belt-and-Road Based Procurement as a Threat to Established Procurement Principles?}

China's advances in both FinTech and cross-border procurement make her rules and practices particularly influential world-wide. Governments use both their financial systems and international procurement to advance their national interests and domestic

systems. Parties to cross-border tenders would generally welcome any move away from international rules imposed from abroad -- and toward their own rules and systems.

${ }^{261}$ See e.g. Kamala Dawar, The WTO Government Procurement Agreement: The Most-Favoured Nation Principle, the GATS and Regionalism, Legal Issues of Economic Integration 42(3), 2015, pp. 257-280, available online.

${ }^{262}$ Sandeep Verma, Use of Country Procurement Systems by MDBs - A Good Time to Switch? User Perspectives Amidst Select Procurement Practices in the State of Rajasthan (India), Proceedings of the University of Nottingham: Public Procurement-Global Revolution VIII Conference, 2017, available online.

${ }^{263}$ See Fred Borson, EU Procurement Policy under Development Aid Financing, European Procurement \& Public Private Partnership Law Review 11, 220, 2016, available online.

${ }^{264}$ Matthias Lehmann, Global Rules for a Global Market Place? - Regulation and Supervision of Fintech Providers, Boston University International Law Journal 38, 118, 2020, available online.

${ }^{265}$ Pietro Ortolani, The Impact of Blockchain Technologies and Smart Contracts on Dispute Resolution: Arbitration and Court Litigation at the Crossroads, Uniform Law Review 24(2), 430-448, 2019, available online.

${ }^{266}$ Almost 25 years ago, authors like Moe and Gilmour noted that government works differently from the private sector procurement in that governments must adhere to particular principles in their public administrative law. See Ronald Moe and Robert Gilmour, Rediscovering Principles of Public Administration: The Neglected Foundation of Public Law, Public Administration Review 55(2) 1995, 135 146, available online. 
policies. $^{267}$ Yet, China's head start in FinTech makes her laws and market practices particularly influential. ${ }^{268}$ Not only does FinTech adoption in China exceed that by value than any other market, but Chinese investment in foreign FinTech ventures gives the country an international presence unrivalled by the EU and US. ${ }^{269}$ China's highly developed FinTech ecosystem will make using other forms of finance in Chinese public procurements less and less practical. ${ }^{270}$

Chinese officials have already promised/threatened to speed up the Fintechization of public procurement internationally. ${ }^{271}$ The Belt and Road Initiative represents $\$ 4-\$ 8$ trillion in cross-border procurements (namely, Chinese government entities buying foreign companies' goods or foreign governments buying Chinese companies' services). ${ }^{272}$ Only about $40 \%$ of countries with Belt and Road Initiatives agreements have procurement provisions in place. ${ }^{273}$ Anyway, $60 \%$ of Chinese companies end up winning these tenders - with procurements done according to much looser rules that those in the West. ${ }^{274}$ The Chinese Government Procurement Law and the related Implementation Rules provide that Chinese public procurement facilitates the achievement of goals designated by state policies. ${ }^{275}$, Plans, like the 2019's Peoples Bank of China's FinTech Development Plan could easily interpret procurement as part of their remit. ${ }^{276}$

China's influence in the Asian Infrastructure Investment Bank (AIIB) could further cement international procurement rules' evolution toward those more similar to Chinese

\footnotetext{
${ }^{267}$ FinTech represents one of many 'innovative policies' governments have sought to promote through procurement. Many authors have argued that international procurement laws have attempted to -- and often failed at -- balancing social and other policies with keeping a level economic playing field internationally. See Christopher McCrudden, Buying Social Justice: Equality, Government Procurement, \& Legal Change, Oxford, 2007.

${ }^{268}$ See Yvon Moysan, China, the World's Biggest FinTech Market, Journal of Digital Banking 2(3), 249258, 2018, available online. See also Unnamed author, Fintech in China: What Lies Ahead, Knowledge@Wharton, 2019, available online.

${ }^{269}$ See Wei Wang and David Dollar, What's Happening with China's Fintech Industry? Brookings Order from Chaos Blog, 2018, available online.

${ }^{270}$ See Ying-ying Zhang-Zhang, Sylvia Rohlfer and Jay Rajasekera, An Eco-Systematic View of CrossSector Fintech:The Case of Alibaba and Tencent, Sustainability 12, 2020, available online.

${ }^{271}$ See Bonnie Buchanan and Cathy Xuying Cao, Quo Vadis? A Comparison of the Fintech Revolution in China and the West, SWIFT Institute Working Paper No. 2017-002, 2017, available online.

${ }^{272}$ Meahl provides the \$4-\$8 trillion number. Green, citing Ghossein (infra note 278), talks about the $60 \%$ of bids being won by Chinese bidders, and adds some extra discussion about finance along the New Silk Road. See Bill Meahl, China's Belt and Road: The New Silk Road? Supply Chain Digital, 2020, available online. See also Will Green, Three Fifths of Belt and Road Contracts go to Chinese Firms, Supply Management Online, 2019, available online.

${ }^{273}$ See Michele Ruta, Matias Herrera Dappe, Somik Lall, and Chunlin Zhang, Belt and Road Economics: Opportunities and Risks of Transport Corridors, 2019, available online, at Table 1.2.

${ }^{274}$ Tania Ghossein, Bernard Hoekman and Anirudh Shingal, Public Procurement in the Belt and Road Initiative, MTI Discussion Paper No. 10, 2018, available online.

${ }^{275}$ Ghossein provides a more extensive analysis of Chinese procurement law in this context. See Government Procurement Law. art. 9. See also Implementation Rules of the Government Procurement Law at art. 6. See Ghossein (supra note 278) at p. 12.

${ }^{276}$ E.g., see Jun Wan, Wei Quan, and Kanxi Liao, FinTech 2020: China, Global Legal Insights, 2021, available online.
} 
rules, rather than those in the West. ${ }^{277}$ Many have seen the AIIB's lending as part of China's broader ambitions to expand its financial services and other markets abroad. ${ }^{278}$ One can easily imagine China's FinTech rules following their FinTech firms worldwide. ${ }^{279}$ As such, if China's FinTech hubs create FinTech standards which large organizations like China Development Bank or AIIB adopt, one could imagine a large number of countries (and even the US or EU) 'receiving' such rules from abroad - rather than developing them domestically/internally. ${ }^{280}$

Much international aid passes through types of public procurement rules which encourage a free-for-all approach to cross-border FinTech-enabled public procurement. ${ }^{281}$ Chinese rules take a laissez-faire approach to FinTech development at home and abroad - with state policy encouraging the adoption of Chinese standards. Western multilateral aid organizations (as previously discussed) aim to use local procurement regulations wherever possible. Banks and other procurement/trade finance providers will, in turn, use the resulting procurements rules at home and abroad. ${ }^{282}$ Until some form of international law comes into place, such finance rules literally take place according to a low bar set by aid organizations' anti-fraud and audit standards. ${ }^{283}$

In theory, FinTech markets could spontaneously evolve the rules needed to guard against such a free for all. Automated procedures in blockchain and smart contracts could add large-scale efficiencies to procurements done by often incompetent or corrupt procurement officials. ${ }^{284}$ Both blockchains and the information provided from the trade of tokens (be they tokens over the consignment rights to cargo to the ownership of a securitized asset) can help ensure aid recipients distribute aid money for its intended

\footnotetext{
277 Jedrzej Gorski, Recent Developments in Procurement of Projects Financed by the Multilateral Development Banks. What Can EU's Public Procurers Expect from the China-Led Financial Institutions?, Chinese University of Hong Kong Centre for Financial Regulation and Economic Development, Working Paper No. 15, 2016, available online.

${ }^{278}$ Many scholars have noted that Chinese MNEs form their own special category of procurement - given their strong government links. See Ravi Ramamurti and Jenny Hillemann, What is 'Chinese' about Chinese Multinationals? Journal of International Business Studies 49, 34-48, 2018, available online.

${ }^{279}$ Sara Hsu and Jianjun Li, China's Fintech Explosion: Disruption, Innovation, and Survival, Columbia Press, 2020.

${ }^{280}$ Frost might oppose such a view, seeing FinTech rules spreading as the benevolent result of gracious policymakers promoting financial inclusion. Few authors see cross-border financial regulation in geopolitical terms. See Jon Frost, The Economic Forces Driving Fintech Adoption Across Countries, BIS Working Paper 838, 2020, available online.

${ }^{281}$ Simon Evenett and Bernard Hoekman, International Cooperation and the Reform of Public Procurement Policies, World Bank Policy Research Working Paper 3720, September 2005, available online.

282 Sope Williams-Elegbe, Public Procurement and Multilateral Development Banks' Law, Practice and Problems, Hart Publishing, 2017, available (in part) online.

${ }^{283}$ Western aid does not completely relinquish their authority to regulate aid contract-related procurement in jurisdictions without sufficiently strong financial management and audit institutions. Yet, in practice, they rely on inefficient local institutions far more than they should. See Verena Fritz, Marijin Verhoeven, and Ambra Avenia, The Political Economy of Public Financial Management Reforms: Experiences and Implications for Dialogue and Operational Engagement, World Bank, 2017, available online.

${ }^{284}$ Government Accountability Office (US), Multilateral Development Banks: U.S. Firms' Market Share and Federal Efforts to Help U.S. Firms, 1995, available online.
} 
purposes and actually spent for those purposes. ${ }^{285}$ Specifically, and the point bares quoting in its whole, "the use of smart contracts in government procurement processes will also require the clarification of liability issues... and interoperability issues will need to be addressed before parties to the WTO GPA can put in place such systems"286 If true, financial technologies will drive international - as well as - national law in FinTechenabled public procurement.

If China does establish the standards under which FinTech-enabled international procurements occur, such standards may - themselves - represent an unfair barrier to internationbal trade. ${ }^{287}$ To that end, an international body -- replacing the Financial Stability Board's (FSB) current de facto role -- should oversee and ensure that FinTech regulations promote a level procurement playing field. ${ }^{288}$ Public procurement authorities have no obvious forum for harmonizing their policies -- like the FSB or WTO. ${ }^{289}$ Disagreements about principles all parties agree might stem from lack of a forum where such disagreements could receive a fair hearing. ${ }^{290}$ Just like national authorities could usefully include procurement officials in their FinTech debates, international bodies could do likewise.

Such a body should not simply attach to an existing international financial organization. Simply creating a FinTech procurement financing working group at the FSB, BIS or OECD would again downplay the important role played by trade finance experts and procuring entity experts themselves. The General Agreement on Procurement (GPA) has no permanent secretariat -- and the GPA does not look at finance issues closely. ${ }^{291}$ If the World Customs Organization, or even the International Telecommunications Union, could get their own standing international organization, why does international procurement still lack such importance? Why not establish an International Public Procurement Authority? Figuring out how to establish a FinTech-enabled procurement regime which promotes the procurement finance domestically and internationally could represent one of its first -- and most important -- tasks. If banks really do disappear (as

${ }^{285}$ Emmanuelle Gann, Can Blockchain Revolutionize International Trade?, WTO Working Paper, 2018 , p. 68, available online.

${ }^{286} \mathrm{Id}$., at p. 69.

${ }^{287}$ Maria Anna Corvaglia, Public Procurement and Private Standards: Ensuring Sustainability Under the WTO Agreement on Government Procurement, Journal of International Economic Law 19(3), 607-627, 2016, available online.

${ }^{288}$ Matthias Lehmann, Global Rules for a Global Market Place? The Regulation and Supervision of Fintech Providers, Boston University International Law Journal 38, 118, 2020, available online.

${ }^{289}$ The regular UNCITRAL meetings related to the Model Law might provide this forum. However, these meetings tend to reflect states' multilateral bargaining power. See Caroline Nicholas, Negotiations and the Development of International Standards in Public Procurement: Let the Best Team Win, Trade Law and Development 7(3), 2015, available online.

${ }^{290}$ Hilde Caroli Casavola, Internationalizing Public Procurement Law: Conflicting Global Standards for Public Procurement, Global Jurist Advances 6(3), 2006, available online.

${ }^{291}$ The WTO hosts regular rounds of GPA negotiations, but plays no role typically served by a procurement policy authority. A standing body would likely focus far more on enforcement and market conduct than policy. See Sue Arrowsmith and Robert Anderson, The WTO Regime on Government Procurement: Challenge and Reform, Cambridge, 2011. 
Satoshi Nakamoto said), such an authority could best figure out how procurement finance could move forward with the new technologies at our great-grandchildren's fingertips.

\section{Conclusions}

How would public procurement change, if major FinTech applications came to work as advertised or promoted by their most optimistic supporters? This paper looks at the four major FinTech applications that could change the way that public procurement information and finance move across transactions. Distributed ledger technologies (including blockchains), smart contracts and tokenization increasingly place real-world processes onto the internet. Such FinTech-enabled public procurement could make government/public buying easier, faster, cheaper, and more transparent. Yet, unmanaged, they could allow for gross violations of public procurement law. Such violations could result in a domestifc and international free-for-all, where contracting authorities procure as they will. Such a free-for-all would certainly jeopardize the principles of equal treatment, non-discrimination, proportionality, and transparency, which have helped safeguard the public interest.

Such a public interest (and its corollaries in procurement principles) needs to guide the development of FinTech for public procurement. Yet, the current haphazard procurements of FinTech -- rather than principled procurement by FinTech -- does little to move FinTech or public procurement forward. The international organizations, wanting to be seen as doing something, distort markets in Fintech innovation and overly push FinTech regulation into the arms of financial regulators. Worse still, these procurements do little to uphold or build upon existing procurement principles enshrined in national and international law.

The current strategy of letting a thousand flowers bloom will result in such a free-for-all. In this free-for-all, contracting authorities will disadvantage future FinTechs, harm the beneficiaries of public spending, and potentially lock-in FinTech-based financing technologies which discriminate, harm disproportionately some, and hide public spending in a black box of inscrutable algorithms. Bespoke regulatory or supervisory technologies can not simply pair up with bespoke FinTech applications - as such technologies lack the kind of guidance that has served traditional supervision for the past century or longer. Changes to national law (particularly administrative law affecting central government and the wider public sector), and work from FinTech associations and advocates in procurement policy bodies will need to guide the development of FinTech-enabled public procurement. Procurement policymakers will need to join the panoply of other interested regulators (most notably financial regulators) to create FinTech applications which benefit all. Few areas of trade finance and broader financial regulation will remain untouched. Hopefully, their regulators will also be similarly revolutionized (disintermediated).

The changes FinTech could cause in cross-border public procurements could also drag along changes in the international law governing them. The Agreement on Government Procurement, the range of UNCITRAL Model Laws (most notably the one on public 
procurement) and the regulations governing procurement financed by multi-lateral donor agencies, all struggle with even adopting e-procurement. Introducing FinTech-based finance into international law will probably require a body dedicated to dragging crossborder procurement finance into the $21^{\text {st }}$ century. Such a body could advise, help set standards, and rein in the free-for-all currently taking place between international organizations and nation-states.

China poses particular risks to a global procurement legal order based on level-playingfield legal principles. China's lead in FinTech and cross-border government procurement -- according to rules aimed at promoting China's interest rather than the global general interest - represent something an international body focused on FinTech-enabled public procurement law could look at. If China sets the rules for the next century's law governing the use of FinTech in public procurement, these rules should ensure adherence to the principles which have grown trade and growth up to now. 